NBER WORKING PAPER SERIES

\title{
PARENTAL INFLUENCES ON HEALTH AND LONGEVITY: LESSONS FROM A LARGE SAMPLE OF ADOPTEES
}

\author{
Mikael Lindahl \\ Evelina Lundberg \\ Mårten Palme \\ Emilia Simeonova \\ Working Paper 21946 \\ http://www.nber.org/papers/w21946 \\ NATIONAL BUREAU OF ECONOMIC RESEARCH \\ 1050 Massachusetts Avenue \\ Cambridge, MA 02138 \\ January 2016
}

We are grateful for comments from Orazio Attanasio, Gerard van den Berg, Richard Blundell, Dalton Conley, Gabriella Conti, Janet Currie, Hans Grönqvist, Krzysztof Karbownik, Robert Östling, André Richter, Torsten Santavirta, Marianne Simonsen and Helena Svaleryd as well as for those from participants at seminars at the University College London, Uppsala University, University of Copenhagen, NBER Summer Institute, Nordic Summer Institute in Labor Economics, Nordic Health Economists' Study Group meeting and Essen Health conference. Mikael Lindahl is a Royal Swedish Academy of Sciences Research Fellow supported by a grant from the Torsten and Ragnar Söderberg Foundation, the Scientific Council of Sweden and the European Research Council [ERC starting grant 241161]. The authors gratefully acknowledges financial support from the Handelsbanken Research Foundation (Lundberg), Swedish Council of Social Research (Palme), Swedish Research Council and the National Science Foundation (Simeonova). The views expressed herein are those of the authors and do not necessarily reflect the views of the National Bureau of Economic Research.

NBER working papers are circulated for discussion and comment purposes. They have not been peerreviewed or been subject to the review by the NBER Board of Directors that accompanies official NBER publications.

(C) 2016 by Mikael Lindahl, Evelina Lundberg, Mårten Palme, and Emilia Simeonova. All rights reserved. Short sections of text, not to exceed two paragraphs, may be quoted without explicit permission provided that full credit, including $(\mathrm{C}$ notice, is given to the source. 
Parental Influences on Health and Longevity: Lessons from a Large Sample of Adoptees

Mikael Lindahl, Evelina Lundberg, Mårten Palme, and Emilia Simeonova

NBER Working Paper No. 21946

January 2016

JEL No. I0,I12,I18,J13

\begin{abstract}
$\underline{\text { ABSTRACT }}$
To what extent is the length of our lives determined by pre-birth factors? And to what extent is it affected by parental resources during our upbringing that can be influenced by public policy? We study the formation of adult health and mortality using data on about 21,000 adoptees born between 1940 and 1967. The data include detailed information on both biological and adopting parents. We find that the health of the biological parents affects the health of their adopted children. Thus, we confirm that genes and conditions in utero are important intergenerational transmission channels for long-term health. However, we also find strong evidence that the educational attainment of the adopting mother has a significant impact on the health of her adoptive children, suggesting that family environment and resources in the post-birth years have long-term consequences for children's health.
\end{abstract}

Mikael Lindahl

University of Gothenburg

Department of Economics

Box 640

SE 40530 Gothenburg

Sweden

Mikael.Lindahl@economics.gu.se

Evelina Lundberg

Uppsala University

Box 513

75120 Uppsala

Sweden

evelina.lundberg@nek.uu.se
Mårten Palme

Department of Economics

Stockholm University

SE-106 91 Stockholm

Sweden

and IZA

Marten.Palme@ne.su.se

Emilia Simeonova

JHU Carey School of Business

100 International Drive

Baltimore, MD 21202

and NBER

emilia.simeonova@gmail.com 


\section{Introduction}

Health inequality and, in particular, the inverse relation between socioeconomic status (SES) and mortality have been documented and discussed in several recent empirical studies (see e.g. Chetty et al., 2015, Deaton, 2003, or Smith, 1999, for overviews). Despite the great research interest in these issues, the mechanisms underlying the empirical regularities observed in data are still controversial. Health and health-related behaviors, leading to differences in longevity, are largely formed by the genetic background and by environmental influences during early childhood and adolescence. Therefore, the intergenerational transmission of health is likely to be an important element of the mechanisms leading to health inequalities.

The aim of this paper is to separate out the importance of pre-birth from post-birth influences in the formation of adult health. We use a large sample of Swedish adoptees for whom we are able to observe measures of adult health status as well as the educational attainment of both biological and adopting parents. We study how the health status and educational attainments of the biological parents - related to genetic factors and in utero health - and the corresponding characteristics of the adopting parents - related to health formation during childhood and adolescence - affect the child's health and mortality later in life.

Our dataset is constructed by matching several different administrative registers containing information on health and educational attainments for biological and adopting parents. We include all adoptees born between 1940 and 1967 in Sweden, in total about 21,000 individuals. As a comparison, we also present results on the same outcomes obtained using the population of about 2.8 million children raised with their biological parents and born in the same time interval as the adoptees. The main outcome of interest is the health status of the adopted children as adults, as measured by adult mortality and hospitalization-based indices. In addition, for females we use the birth outcomes of their first-born child as a measure of the health status of the mother at birth.

We estimate separate models for the association between the child's adult health as an outcome variable and parental longevity and educational attainments. We find a strong association between the longevity of the biological parent and the child mortality risk, which is supported by the results for the other health outcomes. The magnitude of the effect, which is precisely estimated, suggests that one year of additional life expectancy of the biological 
mother is associated with a decrease in mortality of 1.4 percent of the adopted child. The corresponding estimate for the biological father is 1.5 percent. These results are similar to what we obtain using the sample of children raised by their biological parents. There is no significant association between longevity of the adopting parents and the mortality risk of the adopted children.

For adoptees we do not find a lower mortality risk for children with highly educated biological parents, whereas for non-adoptees we do: an additional year of education for either parent is expected to decrease the mortality risk by 2.5 percent. However, for adoptees, we do find a significant effect of the adopting mother's educational attainment. The magnitude of the effect is about the same as for non-adoptees and suggests about a 3 percent reduced mortality risk for every year of additional schooling of the mother. The association vanishes when we include the adopted child's own years of schooling into the specification, suggesting that the effect runs through the educational attainment of the child. When we use other health measures for those individuals in the child generation, we find further support for these conclusions.

The main contribution of the paper is to show that the intergenerational persistence in health and mortality is as strong between the adopted children and their biological parents as for the children raised by their biological parents. This means that a decomposition of the intergenerational transmission of health would attribute all persistence to pre-birth associated with the biological parent's health. ${ }^{1}$ Since this decomposition is robust to adding the educational attainments of the biological parents, we conclude that parental human capital is not among these pre-birth factors. A second main contribution is to show that the association between parental human capital and child's adult health and longevity can be attributed to the adopted parents’ human capital, i.e., to post-birth factors.

In light of previous research, primarily obtained on data from twins (see e.g. Herskind et al., 1996, or Hjelmborg et al., 2006), that attributes a relatively minor role for genetic background to differences in longevity, our decomposition of the intergenerational transmission of health may appear surprising. However, there is a very large share of

\footnotetext{
${ }^{1}$ This is in contrast to what have been found for income, education, wealth, crime, entreprenurship and voting status (Björklund, Lindahl and Plug, 2006; Black et al., 2015; Hjalmarsson and Lindquist, 2013; Lindquist, Praag and Sol, 2015; Cesarini, Johannesson and Oskarsson, 2014).
} 
unexplained variation in in the intergenerational association in health leaving room for important associations with post-birth factors, such as human capital formation.

Although we do not study the effects of any policy initiative our results have obvious policy relevance. The fact that we can reject the hypothesis that the adopting parents' educational attainments have no effect on child longevity implies that policies aimed at leveling out differences between parents associated with different SES will have an effect on child longevity and long term health inequality.

We make several additional contributions. We show that the intergenerational transmission of health in the population is positive and non-trivial, although smaller than what is typically found for outcomes such as education and income, and not driven by the transmission of human capital between parents and children. We also demonstrate that the health status of the biological grandparents affects health at birth of their grandchildren, in the sample of adoptees as well as the rest of the population. These results further underscore the importance of the intergenerational transmission of health.

The analysis in this paper relates to at least five strands of the literature. Most closely, it relates to the quite small literature in epidemiology which uses data on adoptees to study correlations in longevity between adopted children and their biological and adopting parents, respectively (see e.g. Petersen et al., 2005 and 2008, Sørensen et al., 1988). The main research question in this literature is to separate out genetic from environmental factors affecting mortality. Our focus is wider, as we do not only study longevity, but also a range of health outcomes measured throughout the life of the adopted children. Specifically, we consider the effect of parental resources as reflected by their educational attainments. Furthermore, we compare our estimates for adoptees to those obtained on the population of the majority of children raised by their biological parents.

Second, there is a literature in economics using adoptees to decompose the intergenerational association in various other outcomes into pre- and post-birth factors using the regression-based approach we use in this paper (Björklund, Lindahl and Plug, 2006; Black et al., 2015; Hjalmarsson and Lindquist, 2013; Lindquist, Praag and Sol, 2015; Cesarini, 
Johannesson and Oskarsson, 2014). ${ }^{2}$ The closest study is by Thompson (2014), who uses US adoption data to examine the association between adoptive parents' health and the health of the next generation when they were still children. Since his data lack information on the biological parents, he is unable to study the relative importance of genetic endowments and characteristics of the adopting parents.

Third, it relates to studies on the relation between parental resources and child health. An inverse relation between parental SES and child health has been established in several previous studies (see e.g. Case, Lubotsky and Paxson, 2003; Case, Fertig and Paxson, 2005; Palme and Sandgren, 2008; or Smith, 1999, and Almond and Currie, 2011, for reviews). Our contribution vis-à-vis this literature is that we are able to separate out pre-birth factors, attributed to genes and fetal environment, from post-birth ones, attributed to the environment encountered during childhood and adolescence. The formation of this latter period is to a high degree due to parental resources, and can potentially also be influenced by public policy.

An extension of the studies of the association between parental education and child health are the studies aiming at estimating the causal effects of parental education on child health. This literature has documented rather mixed results (Currie and Moretti, 2003; McCrary and Royer, 2011; Lundborg et al., 2013). Although we estimate the association of the educational attainments of both the biological and the adopting parents with child health, the association can easily be attributed to a "third factor" that we are unable to identify using our research strategy. That is why our estimates should rather be interpreted as a "decomposition" of the influence of pre- and post-birth factors potentially related to child health, or a causal effect of parental education and all post-birth factors that can be correlated with it.

A fourth strand of the related literature consists of studies on the genetic influences on human longevity. This literature has primarily used data on twins and family members. The consensus from these studies is that there is a quite weak correlation (see e.g. Finch and Tanzi, 1997) in the length of the life span between parents and offspring (0.01-0.15; Cohen, 1964; Wyshak, 1978). Since siblings in general also share the same environment during their

\footnotetext{
${ }^{2}$ See also Sacerdote, 2006 who studies measures of height and weight using a sample of Korean adoptees (where information on the biological parents is unavailable) and Fagereng et al. (2014) who look at financial decisionmaking.
} 
upbringing, the correlations between them are in general somewhat stronger. Later studies have developed structural models using data on pairs of mono- and dizygotic twins to decompose differences in genetic and environmental factors (see e.g. Herskind et al., 1996, or Hjelmborg et al., 2006).

Our study differs from these studies in several respects. First, the pre-birth factors in this study also include potential influences during the in-utero period, in addition to genetic influences. Second, and more importantly, since siblings in general are brought up in the same environment, these studies are not able to identify the separate effect of parental characteristics on children's long-term health as we do in this study.

Finally, we make a contribution to the field of studies on social mobility. There is a large empirical literature on social mobility (see e.g. Solon, 1999 and Black and Devereux, 2010, for overviews). Although the topic of how health is transmitted between parents and their children has a long history in science, starting with Galton (1889), and given the importance of health in discussions about inequality in well-being, surprisingly little is known about the transmission of health and longevity across generations. There are only a few studies that have been able to study the association between adult health indicators for parents and children in representative samples (e.g., Trannoy et al, 2010; Classen, 2010; Johnston et al., 2013). Since we present estimates of the intergenerational associations for the population of children raised with their biological parents, as a comparison to the results obtained on adoptees, our paper indirectly relates to this literature.

A strand of the literature on social mobility studies the association in birth weight across generations (see e.g. Currie and Moretti, 2007). Because one of our health outcomes is birth weight of the first born child of the adoptee, our study relates to this literature extends it by estimating how the health status of the biological grandparents is associated with health at birth of their grandchildren. We show this in the sample of adoptees as well as the rest of the population.

The rest of the paper is organized as follows. The next section describes the conceptual framework for identifying pre- and post-birth factors in the association between parental education and child adult health. Section 3 provides a brief historical background and a description of institutions surrounding adoptions in Sweden. Section 4 presents the data and descriptive statistics and the results are presented in Section 5. Finally, Section 6 concludes the paper. 


\section{Empirical Specifications}

We first estimate the following intergenerational model on the population of individuals

$$
H_{j}^{b c}=\beta_{0}+\beta_{1} Y_{j}^{b p}+v_{j}^{b c}
$$

where $H_{j}^{b c}$ represents adult health status for the biological child and $Y_{j}^{b p}$ the biological parents' health status or educational attainment. Subscript $j$ indexes the family in which the child is born and raised and superscripts $b c$ and $b p$ denote the biological child and parent, respectively; $v_{j}^{b c}$ is the child-specific error term assumed to be uncorrelated with $Y_{j}^{b p}$. The coefficient $\beta_{1}$ measures the strength of the association between adult health of the child and health or human capital measures of the parents and is a combined effect of many different factors such as genetics, prenatal environment and environment during childhood and adolescence.

As we have data on the characteristics of adoptees and their biological and adoptive parents, we estimate the following model on the population of adoptees: ${ }^{3}$

$$
H_{i}^{a c}=\alpha_{0}+\alpha_{1} Y_{j}^{b p}+\alpha_{2} Y_{i}^{a p}+v_{i}^{a c}
$$

where $Y$ once more measures health or human capital inputs that are transmitted from the biological parent $b p$, or the adoptive parent $a p$, to the adopted child $a c$ born in family $j$ and adopted and reared in family $i ; v_{j}^{a c}$ is a child-specific error term uncorrelated with $Y_{j}^{b p}$ and $Y_{i}^{a p}$

Before we discuss how we can interpret $\alpha_{1}$ and $\alpha_{2}$, let us state the following key assumptions of the adoption design:

1) Adoptees are conditionally randomly assigned to adoptive families;

2) The adoption should have taken place close to birth so that it is possible to accurately separate pre and post birth effects;

\footnotetext{
${ }^{3}$ We follow the strategy to separate pre- and post-birth effects from Björklund et al. (2006).
} 
3) The postnatal pre-adoption environment (e.g., the quality of the nursery homes) is uncorrelated with the genetic background and the post adoption environment (or has no influence on the health of the adopted child); and

4) the biological parents have no contact with the adopted child post adoption.

Under these four assumptions, we are able to separately estimate the association between adult health status and the observable pre- and post-birth characteristics $Y$ by estimating equation (2) using data on adopted children and their biological and adoptive parents. In general, $\alpha_{2}$ does not only capture the importance of the adoptive parental characteristic under study, $Y_{i}^{a p}$, but also everything else in the adoption family that is correlated with $Y_{i}^{a p}$. We interpret the estimates as a measure of the importance of transmission channels stemming either from the pre- or post-birth environment. Assuming that adoptees and non-adoptees are drawn from the same distribution, we are also able to decompose an estimate of $\beta_{1}$ to separate entities of pre- and post-birth factors, captured by estimates of $\alpha_{1}$ and $\alpha_{2}$, which are then interpretable for the population of children. We will discuss these issues further below.

The first assumption listed above, that adoptees are conditionally randomly assigned to adoptive families, can be questioned in all empirical studies using data for adoptees (see further the discussion in Section 4.4). We do three sets of sensitivity analyses to check the robustness of our main results with respect to this assumption. First, we look at the robustness of the main findings with respect to changes in the set of confounding parental characteristics that we can control for. We also employ the method suggested by Altonji et al. (2005) to get an estimate of how much any unobservable characteristics correlated between the biological and the adopting parents must contribute, relative to the contribution of the observable characteristics, in order to explain away the main results obtained in the study.

Second, we restrict the sample to include only adoptees that moved from their municipality of birth. We cannot directly observe whether relatives or friends of the biological parents adopted some children, but in such cases, children are more likely to stay in the municipality where they were born. Moreover, adopted children who move from their municipality of birth are much less likely to interact with their biological parents post adoption. 
In the third sensitivity analysis, we restrict the sample of adoptees to first-borns of their biological mothers. The motivation for this restriction is to exclude adoptees who were given up for adoption because of illness, poverty or other reasons for inabilities to accommodate a large family of the biological parents, which, in turn, will increase the probability that the adopting parents are related to the biological ones. That is, first-borns are more likely to be given away for adoption simply because they are less likely to have been planned by their biological parents or born in established families.

\section{Adoptions in Sweden 1940-1967}

\subsection{The History and Institutions of Adoptions}

Adoptions in the period when the children we study in this paper were born were very different from what they are today, in Sweden and in most other Western industrialized countries. At that time, they were dominated by children born in Sweden, and their biological parents were in most cases young and lacked economic resources, or were stigmatized by having an unplanned child, which prevented them from taking care of the baby. International adoptions, although started already in the 1950s, did not overtake domestic adoptions until in the late 1960s.

Domestic adoptions in Sweden have been described in several previous academic works and government documents. Two studies, Bohman (1970) and Nordlöf (2001), use primary sources. Bohman (1970) gives a broad overview and presents results from different empirical comparisons between adoptees and non-adoptees. Nordlöf (2001) focuses on adoptions in the city of Stockholm between 1919 and 1973. She uses archival records from the Stockholm child welfare office (Barnavårdsnämnden), which administrated adoptions, to give a description of the adopted children and their families. Several empirical studies using adoptee data, e.g. Björklund et al. (2004) and Oskarsson et al. (2015), also give comprehensive overviews of adoptions in Sweden.

Sweden had its first law regulating adoptions in 1917. This law was changed on several occasions since it was first implemented. However, the original law prescribed several principles that are still in use. One such principle is that the adoption should be "in the best interest of the child", both regarding whether or not the adoption should take place at all and the choice of adopting parents. Another principle was that no payments were allowed between 
the adopting and the biological parents. Finally, the adopted child should have all the rights regarding inheritance from the adopting parents that their biological children would have had. ${ }^{4}$

The law also prescribed that the adoption should be finalized in a court decision. All administrative work preparing for the adoption, including all contacts with the biological and the adopting parents, were carried out by the child welfare offices (Barnavårdsnämnderna). An adoption could be cancelled if both the adopting parents and the child agreed on it when the child had reached the age of majority, or as the result of misbehavior of either party. The latter category included different kinds of abuse of the child as well as general criminal behavior. In 1944, the law was extended to also include major health problems and defects of the adopted child. However, Nordlöf (2001) concludes that cancellations of adoptions were extremely rare in the Stockholm area in the period 1918-1973.

\subsection{The Biological Parents}

Bohman (1970) and Nordlöf (2001) give a fairly consistent description of the mothers who gave up their children for adoption: ${ }^{5}$ they were on average substantially younger than mothers who kept their children; they were, except for a few rare cases, unmarried or divorced; and they did, on average, have a lower socio-economic status as compared to the rest of the population, although the differences were quite small. The largest occupational category of these mothers in Nordlöf's study was maids (26 percent), followed by office workers (18 percent) and restaurant workers (15 percent). In most cases, the child was voluntarily given up for adoption with the predominant reason being lack of housing and economic resources for supporting the child. In some very rare cases, it was because the mother died when giving birth or because she suffered from severe health problems. ${ }^{6}$

\footnotetext{
${ }^{4}$ The main principle was that the adopted child's rights to inherit his or her biological parents were lost. However, until 1959, some legal connection was kept between the biological parents and the adopted child. These adoptions are sometimes called weak adoptions and entailed that the child was still the heir of her/his biological parents and they were responsible for supporting the child economically if the new adopting parents could not. These legal responsibilities did not imply any further contact between the child and the biological parents. From 1959 onwards, these kinds of weak adoptions do no longer occur and in 1971, all weak adoptions were retroactively made strong, i.e., all legal ties were also cut between the biological parents and the child. ${ }^{5}$ In Section 4, Descriptive Statistics, we return to comparisons between the characteristics of the biological mothers who gave up their children for adoptions and those who did not.

${ }^{6}$ In our sample, this is very rare because of the sample restrictions we have made. The restrictions require that parents are present in the Census in the year 1960. Most of our adoptees were born in the period prior to that. However, in the later period, we have about 70 children who have mothers that died close to birth (own birth or adopted sibling's birth). Excluding these children does not affect our results.
} 
Bohman (1970) has a description of the biological fathers. Similar to the mothers, they were, on average, younger than those who did not give up their children for adoption; they had a slightly lower average education level, although the difference was quite small; and they had a higher rate of registered alcohol abuse and crime rate.

Nordlöf attributes the rapid decline in domestic adoptions by the end of the 1960s to changes in social policy - including the introduction of housing allowances, the improvement of general housing conditions, increased child allowances and the introduction of childcare. Other important changes in society were the reduced social stigma of having children without being married or being in a steady relationship, the increased availability and usage of contraceptives, and the liberalization of the legislation for abortion. ${ }^{7}$

\subsection{The Adopted Child}

Most adoptions took place when the child was an infant. The mother had to wait until she had recovered from delivery before she could make the final decision to give the child up for adoption. The child was therefore initially placed in a nursery home and thereafter placed in a prospective adoptive family. The recommendation was that the placement be made before the child was six months old and that the trial period should be between three to six months. If the trial period went well, the adoptive parents would apply to the court for a legal adoption decision.

The children underwent a medical examination before they were adopted. The recommendations for this procedure were described in the Handbook for Social Workers (see e.g. Allmänna barnhuset, 1955). Nordlöf (2001) writes that children with physical or mental defects were in general not adopted, but stayed in foster care homes. This was also true for children whose mothers were prostitutes or who were conceived after a rape.

Bohman (1970) finds no significant difference in health at age 10-11 between his sample of adoptees and a control group of non-adoptees of the same age. Oskarsson et al. (2015) interpret this lack of difference as a net effect of two counteracting forces. Adoptees are to a larger extent than non-adoptees born by low SES mothers, which would indicate that they have inferior health. However, as a result of the medical testing before the adoptions took

\footnotetext{
${ }^{7}$ A law allowing abortion without any particular reason until the end of week 18 in the pregnancy was passed in 1974. It was, however, preceded by a gradual increase in the number of abortions over the previous decade, as the necessary conditions for obtaining a legal abortion were relaxed.
} 
place, children who were eventually adopted are positively selected from this group. ${ }^{8}$ In addition, the adoptive parents do often represent higher SES households, which could also have a positive impact on adopted children's health.

\subsection{The Adopting Parents}

The legal requirements for adopting were few; adoptive parents had to be free of tuberculosis, sexually transmitted diseases and be at least 25 years old. In practice, local social authorities followed the recommendation that the adopting family should be young enough to be able to be the biological parents, they had to have adequate housing and they should be married. Furthermore, the father should have a steady income, also implying that the mother should be able to stay at home. The adopting family's suitability for taking care of a child was evaluated by the child welfare offices (Barnavårdsnämnderna).

Until 1944, families with own biological children were not allowed to adopt. Nordlöf (2001) documents that it was rare that these families were admitted to adopt also after 1944, since there was always a shortage of children available for adoption and the child welfare offices considered it a disadvantage to have own biological children. This convention did, to a large extent, rule out adoptions in the immediate families of the biological mother or father, such as their mothers or siblings. Nordlöf (2001) estimates such adoptions by close relatives to be only around 1 percent of all adoptions in her sample.

\subsection{Matching of Children and Adopting Parents}

The social workers were instructed to find adopting parents that fit the child given up for adoption (see e.g. Allmänna barnhuset, 1955). Characteristics such as height and eye color were mentioned in the instructions. However, as pointed out by Björklund et al. (2004), the information available to the social worker about the biological mothers was likely to be quite limited. This was also acknowledged in the instructions, which is reflected in the following quote: “The social worker's ambition to find an adoptive home that fits a specific child particularly well is often unrealistic. The important task is to find good adoptive parents who can be expected to give children in general good conditions."9

\footnotetext{
${ }^{8}$ In Section 4, Descriptive Statistics, we compare the health status in our sample of adoptees to non-adoptees in the same age group.

${ }^{9}$ This quotation is originally from Allmänna barnhuset (1969) and was obtained by us from Björklund et al. (2004).
} 
The prospective adopting parents were able to post requests for characteristics of the child based on heredity. According to Nordlöf (2001), very few used that opportunity in other ways than just stating that they wanted a "healthy child". In very rare cases there were requests for children of mothers with good grades in school. The biological mothers were also able to post requests concerning the prospective adopting parents. Again, very few used that opportunity. Nordlöf (2001) found one request for an "intellectual” and one for an "artistic" family in her material.

From the instructions to the social workers, there are no indications that direct matching on health status between the prospective adopting parents and the child took place.

\section{Data and Descriptive Statistics}

\subsection{Sample Definition}

We use data from different national registers in Sweden and include all males and females born in Sweden between 1940 and 1967. ${ }^{10}$ The Multigenerational Register (see Statistics Sweden, 2009) contains information on whether or not a person was adopted as a child. It also contains a personal identifier of the biological mother and father (if known to the authorities) as well as the adopting mother and father.

Table 1 shows the number of observations for the two populations used in this study - adoptees and, as a comparison, non-adoptees - at different stages of the sample selection process. There are in total 64,889 adoptees that we can identify in our data. About 30,000 of these were adopted by only one parent, in most cases the husband of the child's biological mother. We excluded these individuals from the analysis. We construct two samples from the remaining population. First, a larger sample, including 21,206 individuals for whom we have information on the biological mother as well as the adopting mother and father and, second, a smaller sample of 10,837 individuals, where we also have information on the biological father.

\footnotetext{
${ }^{10}$ The lower cohort restriction is motivated by data availability and the upper one by the fact that domestic adoptions in Sweden decreased rapidly in the late 1960s.
} 
Table 1. Sample sizes at different stages of the sample selection process.

\begin{tabular}{lcc}
\hline Born in Sweden 1940-67 & Non-adoptees & Adoptees \\
\hline Non-adopted & $3,061,504$ & \\
Adopted by at least one parent & & 64,889 \\
Adopted by both parents & & 33,312 \\
Not adopted by own parents & & 33,266 \\
Adopting parents' age is correct * & $3,048,981$ & 30,876 \\
Not died or emigrated first year & $3,004,251$ & 30,862 \\
Biological mother is identified & $2,909,451$ & 22,695 \\
Parents' education is known & $2,828,078$ & 21,206 \\
Biological father is identified & & 10,837 \\
\hline
\end{tabular}

*Adopting mother age 25-47 and adopting father age 25-66 at birth of adopted child.

Figure 1 shows the number of adoptees that we are able to identify in our data by year of birth by different categories. The top curve shows the total number of adoptees with two adopting parents that we are able to identify. The dashed and the thick solid lines below show the observations that we are able to identify, given different data requirements indicated below the figure. It is evident from the figure that for those born in the first half of the 1940s, we are able to use quite a small share of the observations, since we are not able to observe data on their biological parents.

Figure 1 also shows that there is an increase in the number of adoptees between 1940 and 1945. This primarily reflects the increase in the overall fertility rate in Sweden. As we discussed in Section 3, there are several reasons for the decline in adoptions between 1945 and 1967. ${ }^{11}$ The decrease in domestic adoptions towards the end of our study period was offset by an increase in international adoptions. The number of adopted children for whom we can identify the biological mother increases during the 1940s.

\footnotetext{
${ }^{11}$ Figure A1 in the Appendix shows the ratio of adopted children in birth cohorts 1940-1967, which documents the same trends.
} 


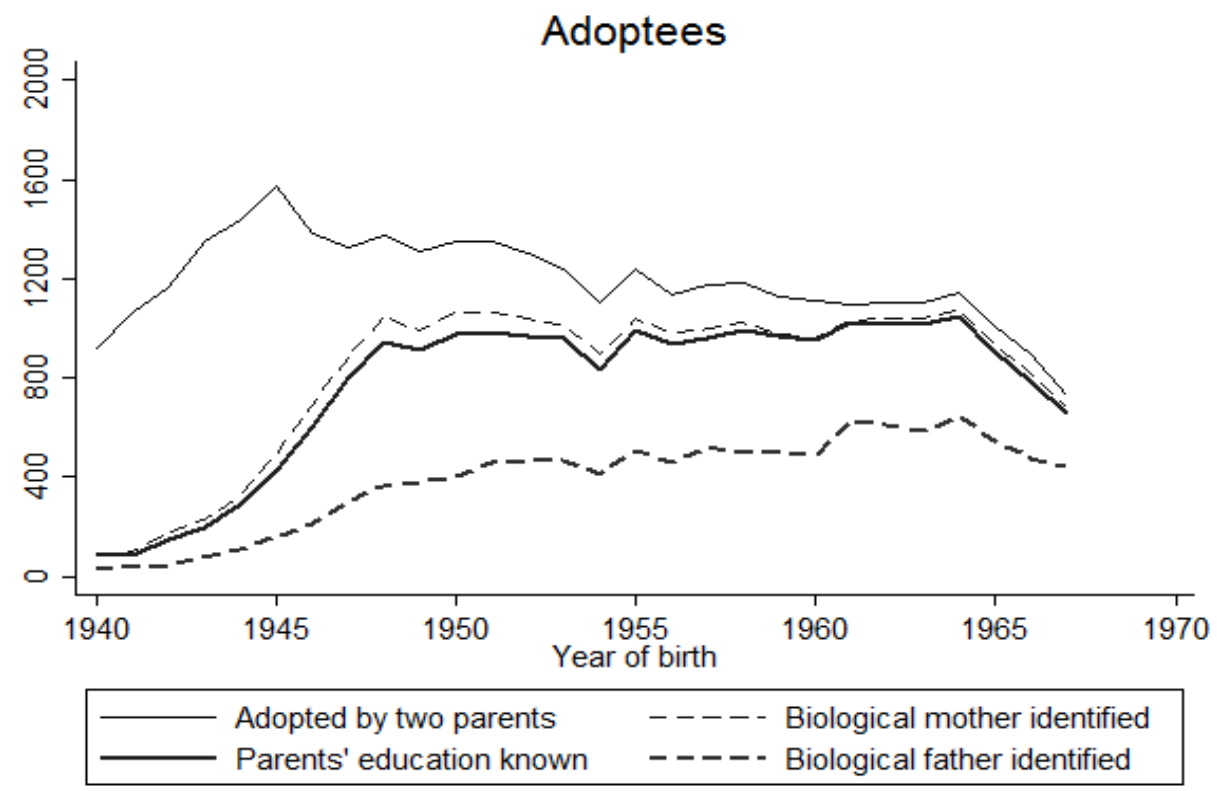

Figure 1. Swedish domestic adoptions by year of birth of the adoptees.

\subsection{Variable construction}

\subsubsection{Mortality and Life Expectancy}

Data on date of death are used for constructing two of the three dependent variables that apply to the child generation. They are also used in constructing the independent variable that applies to the parent generation. Information on date of death is obtained from the national Cause of Death Register (see Statistics Sweden, 2009). The Cause of Death Register records dates and ICD codes for the underlying cause of death for all deaths in Sweden from 1952 and onwards. Our observation period stops on April 1, 2013. This implies that for the child generation, we can observe the oldest person in our sample until age 73 and the youngest until age 45 .

Figure 2 shows the number of deaths by year of birth and broken down by the most common causes of death in our sample, which are circulatory diseases, cancer and all other causes of death. The left-hand panel corresponds to the sample of adoptees and the right-hand panel to the comparison group of non-adoptees. Comparing the death rates in the two panels, it can be seen that it is somewhat higher among adoptees and that the graphs for adoptees are quite noisy as a result of small sample sizes. The share of deaths is quite low for the younger age groups. For the parent generation, right censoring of date of death is less of a problem. As 
we explain below, we use hospitalization data in order to predict the date of death for the parents for whom we are unable to observe age at death.
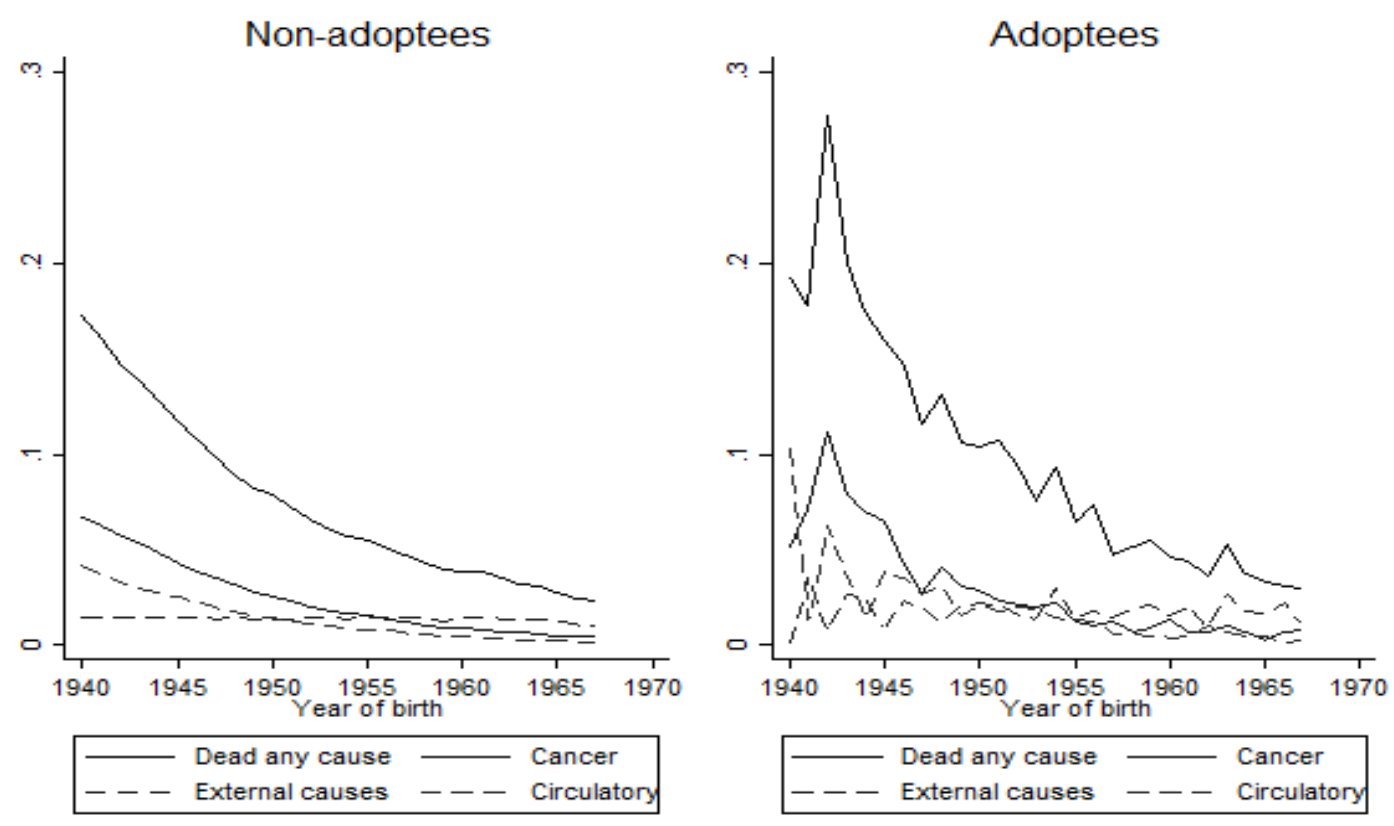

Figure 2. Share of individuals in the sample who died before April 1, 2013. Non-adoptees in the left-hand panel and adoptees in the right-hand panel. ${ }^{12}$

The top panel in Table 2 shows the distribution of all deaths by the main underlying cause of death observed in the sample of adoptees and the comparison group, respectively. The six most common causes of death according to the main chapter in the ICD 10 code are included together with a seventh category, "Other”, corresponding to all causes not included in the six most common ones. The last column in Panel A of Table 2 shows the $p$-values for a test of equality between the shares of deaths in the two samples that can be attributed to each of the causes considered. The result is that the distributions are quite similar, although adoptees are somewhat less likely to die from cancer and more likely to die from diseases in the digestive organs and from mental disorders. ${ }^{13}$

\footnotetext{
${ }^{12}$ Note that the graphs with share of deaths among adoptees are less smooth than the corresponding graphs for non-adoptees. This is because of the much smaller sample size among adoptees, especially for the early cohorts (for the number of adoptees by birth cohort, see Figure 1).

${ }^{13}$ The figures are not adjusted for educational attainment or other measure of SES, which could explain the differences. We also know from previous research that adoptees have worse mental health than non-adoptees
} 
Table 2. Share of deaths (Panel A) and hospitalization (Panel B) by cause and $p$-values of test for equal share in the group of adopted and non-adopted children. Non-adoptees are weighted by cohort size to be comparable with adoptees.

\begin{tabular}{lccc}
\hline & $\begin{array}{c}\text { Non-adoptees } \\
\text { (weighted) }\end{array}$ & $\begin{array}{c}\text { Adoptees } \\
\text { (large sample) }\end{array}$ & $\begin{array}{c}p \text {-values } \\
\text { mean diff }\end{array}$ \\
\hline Panel A: Causes of death & & & \\
\hline Cancer & 0.301 & 0.254 & 0.0000 \\
External causes & 0.233 & 0.229 & 0.7064 \\
Circulatory & 0.165 & 0.181 & 0.0936 \\
Digestive & 0.039 & 0.059 & 0.0007 \\
Mental & 0.022 & 0.035 & 0.0048 \\
Respiratory & 0.030 & 0.032 & 0.6156 \\
Other & 0.210 & 0.209 & 0.9772 \\
\hline Share of deaths & 0.058 & 0.077 & 0.0000 \\
Tot \# of deaths & 200,350 & 1,634 & \\
\hline Panel B: Causes of hospitalization & & & 0.0000 \\
\hline Cancer & 0.095 & 0.071 & 0.1464 \\
External causes & 0.097 & 0.099 & 0.0000 \\
Circulatory & 0.092 & 0.082 & 0.0000 \\
Digestive & 0.097 & 0.089 & 0.0000 \\
Mental & 0.142 & 0.202 & 0.0000 \\
Musculoskeletal & 0.065 & 0.060 & 0.0000 \\
Genitourinary & 0.066 & 0.057 & 0.0017 \\
Other & 0.346 & 0.341 & 0.0000 \\
\hline Mean \# hospitalizations/person & 0.6037 & 0.6619 & \\
Tot \# hospitalizations & $7,536,949$ & 75,389 & \\
\hline
\end{tabular}

\subsubsection{Hospitalization}

Data for our measures of hospitalization are obtained from the national In-patient Register (see Statistics Sweden, 2009). The national In-patient Register includes dates for all hospital stays at Swedish hospitals. This register has a national coverage starting in 1987, and we have access to data for the entire period until 2012. Since the first birth cohort included in our data was born in 1940, we observe all their hospital stays from age 47 and until age 72 . The Inpatient Register includes ICD codes for the maximum of eight different medical causes of each hospital stay.

(see e.g. Miller et al., 2000). Included in digestive causes are K70 (ICD 10), which is alcohol-related liver disease. The mean of K70 is 0.027 among adoptees, and 0.016 among non-adoptees. This implies that about half of the adoptees' digestive death is alcohol related, and the figure is slightly lower for non-adoptees. This does not explain the entire difference, however. 
We use two measures of health from the hospitalization data. The first, labeled "Hospitalization", is simply the residuals from a linear probability model regression of an indicator variable for whether or not the individual has been in hospital care for each year separately during the observation window on year and year of birth indicators. In a second step, we average the residuals for each individual to obtain the measure. This procedure accounts for differences in the probability of hospitalization over the life cycle and we may therefore interpret the resulting variable as a measure of lifetime hospitalization.

The second measure, labeled "Health index", is constructed in three steps. ${ }^{14}$ First, for every year, we use a probit model to regress an indicator variable, equal to one if the individual has died within five years and zero otherwise, on the information from the inpatient register for that year (days, visits, diagnoses). ${ }^{15}$ In a second step, we create a health index ranging between 0 and 1 by predicting the risk of dying within five years. Finally, repeating the procedure from the "Hospitalization" measure, we take out year and cohort effects by regressing the predictions on a full set of year and year of birth indicators. For each individual, we then average the residuals to obtain the index. Note that a high score on the health index, just as for the hospitalization measure, means worse health. The advantage of this measure compared to "Hospitalization" is that it weights the different diagnoses by "severity" based on how likely the person is to die within five years.

We use a two-step procedure to handle the problem of right censoring of date of death in the parental generation. We first use the actual date of death for those who were deceased before April 1, 2013 as a dependent variable in a censured OLS regression on days in hospital, number of hospital visits as well as indicators for diagnoses interacted with cohorts. In the second step, we use the estimates from the model to predict the date of death for those who are still alive in April 2013. We do this separately for men and women, since the health status and the probability of seeking care differ between the gender groups.

Panel B in Table 2 shows the shares of the most common causes of hospitalization by main ICD 10 chapter for the groups of adoptees and non-adoptees, respectively. Similarly to the causes of death, the largest differences are in the diagnoses related to problems in the digestive organs and mental disorders.

\footnotetext{
14 The first two follow Cesarini et al. (2015).

${ }^{15}$ We use the first two digits in the ICD10 diagnosis codes (one letter and one number), which constitutes about 200 different categories. We do this for the first two diagnoses for each hospital stay. In addition, we include linear variables for the number of hospital stays and the total number of days in hospital care.
} 


\subsubsection{Measures Based on Birth Outcomes}

Previous research has established that birth outcomes to a large extent reflect the health status of the mother (see e.g. Currie, 2011). Further, weight at birth, and in particular low birth weight (below 2500 gr) is very strongly correlated with health outcomes later in life. This relation enables us to use the birth outcomes of the children of the female adoptees included in our sample as a health measure. Our data source is the National Swedish Birth Register (see Statistics Sweden, 2009). This birth register contains a large amount of information on all births in Sweden from 1973 and onwards. Using the Multigeneration Register, we are able to link births to the adoptee included in our sample.

We use four different birth outcome measures: (1) An indicator for low birth weight, i.e. a birth weight below 2,500 grams; (2) Birth weight measured in grams; (3) An indicator of the APGAR score at five minutes after the birth being below the maximum score of 10; (4) The APGAR score after five minutes. ${ }^{16}$

\subsubsection{Educational Attainments}

The number of years of obtained schooling in the parental generation is a key independent variable in our empirical analysis. Our main data source for this variable is the 1970 Census. If the information is missing in that Census year, we use data from the 1990 and 2004 waves of the Swedish Education register. As a third option for observations that are still missing, we use the 1960 Census. ${ }^{17}$ Overall, we are able to identify educational attainment for 97 percent of the sample. Education in Swedish registries is recorded at seven different levels, which we translate into years of schooling. ${ }^{18}$

\footnotetext{
${ }^{16}$ The APGAR score is a summary measure recorded by the midwife very shortly after birth and at given times, with the purpose of summarizing the health status of newborn children. It uses five different criteria: Complexion, Pulse rate, Reflex irritability grimace, Activity and Respiratory effort. It is named as a backronym of the included indicators (Appearance, Pulse, Grimace, Activity, and Respiration) as well as after the anesthesiologist Virginia Apgar, who suggested the score in 1952.

${ }^{17}$ A problem with the 1960 Census is that the coding of educational attainment is different from our other data sources. We therefore use data from individuals that are present is both the 1960 and 1970 census, and are 35-45 years old in 1960, to predict years of schooling from the 1960 census for those missing observations.

${ }_{18}$ Pre-comprehensive school compulsory level $=7$ years; 2 comprehensive school or junior secondary school = 9 years; vocational school $=10.39$ years, secondary school $=12.19$ years; secondary school +1 or 2 years $=14$; college or university $=16$ years; and $\mathrm{PhD}=20$ years.
} 


\subsection{Descriptive Statistics}

Table 3 contains sample means and standard deviations (within parentheses) for the main outcome and control variables in the sample of adoptees and non-adoptees. Columns 3 and 5 show descriptive statistics for adoptees that are weighted by the size of the cohorts for non-adoptees. The first panel shows information on the children of the two samples. The second panel shows descriptive statistics for the biological parents. On average, the biological parents of the adopted children have slightly less education and a shorter life expectancy compared to those of the non-adopted. The third panel shows descriptive statistics of the adopting parents. Adopting fathers have almost one additional year of education compared to the biological fathers of the adopted children. 
Table 3. Summary statistics of main outcome and control variables

\begin{tabular}{|c|c|c|c|c|c|}
\hline & Non-adoptees & $\begin{array}{l}\text { Adoptees - Bio } \\
\text { father known }\end{array}$ & $\begin{array}{l}\text { Adoptees - Bio } \\
\text { father known } \\
\text { (weighted) }\end{array}$ & $\begin{array}{c}\text { Adoptees - } \\
\text { Large sample }\end{array}$ & $\begin{array}{c}\text { Adoptees - } \\
\text { Large sample } \\
\text { (weighted) }\end{array}$ \\
\hline \multicolumn{6}{|c|}{ Children } \\
\hline \multirow[t]{2}{*}{ Female } & 0.488 & 0.481 & 0.477 & 0.478 & 0.476 \\
\hline & $(0.500)$ & $(0.500)$ & $(0.500)$ & $(0.500)$ & $(0.499)$ \\
\hline \multirow[t]{2}{*}{ Dead by April 2013} & 0.071 & 0.067 & 0.086 & 0.077 & 0.095 \\
\hline & $(0.257)$ & $(0.250)$ & $(0.281)$ & $(0.267)$ & $(0.294)$ \\
\hline \multirow[t]{2}{*}{ Hospitalization (mean residual) } & 0.009 & 0.029 & 0.030 & 0.029 & 0.030 \\
\hline & $(0.104)$ & $(0.124)$ & $(0.128)$ & $(0.125)$ & $(0.128)$ \\
\hline \multirow[t]{2}{*}{ Health index (mean residual) } & 0.001 & 0.002 & 0.002 & 0.002 & 0.003 \\
\hline & $(0.015)$ & $(0.016)$ & $(0.018)$ & $(0.016)$ & $(0.017)$ \\
\hline \multirow[t]{2}{*}{ Years of schooling } & 11.718 & 11.533 & 11.360 & 11.537 & 11.397 \\
\hline & $(2.776)$ & $(2.400)$ & $(2.529)$ & $(2.455)$ & $(2.533)$ \\
\hline \multirow[t]{2}{*}{ Birth weight first own child (women) } & 3417.149 & 3392.872 & 3395.697 & 3401.001 & 3404.688 \\
\hline & $(566.315)$ & $(597.790)$ & (592.298) & $(594.842)$ & (593.157) \\
\hline \multirow[t]{2}{*}{ Low birth weight own child (women) } & 0.052 & 0.066 & 0.064 & 0.063 & 0.061 \\
\hline & $(0.223)$ & $(0.248)$ & $(0.245)$ & $(0.243)$ & $(0.239)$ \\
\hline \multirow[t]{2}{*}{ APGAR 5 min } & 9.526 & 9.510 & 9.505 & 9.492 & 9.501 \\
\hline & $(0.960)$ & $(0.980)$ & $(0.999)$ & $(1.015)$ & $(1.013)$ \\
\hline \multirow[t]{2}{*}{ Low APGAR 5 min } & 0.336 & 0.343 & 0.344 & 0.352 & 0.343 \\
\hline & $(0.472)$ & $(0.475)$ & $(0.475)$ & $(0.478)$ & $(0.475)$ \\
\hline \multicolumn{6}{|c|}{ Biological parents } \\
\hline \multirow[t]{2}{*}{ Dead by April 2013, mother } & 0.568 & 0.495 & 0.671 & 0.516 & 0.668 \\
\hline & $(0.495)$ & $(0.500)$ & $(0.470)$ & $(0.500)$ & $(0.471)$ \\
\hline \multirow[t]{2}{*}{ Age at death, mother } & 77.543 & 69.764 & 75.018 & 71.135 & 75.503 \\
\hline & (12.188) & $(13.730)$ & (12.539) & $(13.235)$ & $(12.327)$ \\
\hline \multirow[t]{2}{*}{ Predicted age at death, mother } & 81.241 & 76.967 & 78.387 & 77.509 & 78.779 \\
\hline & $(10.586)$ & $(12.472)$ & $(11.690)$ & $(12.048)$ & (11.448) \\
\hline \multirow[t]{2}{*}{ Years of schooling, mother } & 8.235 & 8.095 & 7.837 & 8.128 & 7.895 \\
\hline & $(2.140)$ & $(1.754)$ & $(1.584)$ & $(1.816)$ & $(1.666)$ \\
\hline \multirow[t]{2}{*}{ Dead by April 2013, father } & 0.741 & 0.682 & 0.812 & & \\
\hline & $(0.438)$ & $(0.466)$ & $(0.391)$ & & \\
\hline \multirow[t]{2}{*}{ Age at death, father } & 74.513 & 70.534 & 73.879 & & \\
\hline & $(11.820)$ & $(11.562)$ & (11.058) & & \\
\hline \multirow[t]{2}{*}{ Predicted age at death, father } & 77.004 & 74.278 & 75.667 & & \\
\hline & $(11.257)$ & $(11.310)$ & $(10.830)$ & & \\
\hline \multirow[t]{2}{*}{ Years of schooling, father } & 8.781 & 8.384 & 8.120 & & \\
\hline & $(2.774)$ & (2.173) & $(2.045)$ & & \\
\hline & & doptive parents & & & \\
\hline Dead by April 2013, mother & & 0.650 & 0.596 & 0.682 & 0.598 \\
\hline & & $(0.477)$ & $(0.491)$ & $(0.466)$ & $(0.490)$ \\
\hline Age at death, mother & & 79.068 & 78.501 & 79.568 & 78.425 \\
\hline & & (11.234) & $(11.571)$ & $(11.166)$ & (11.685) \\
\hline Predicted age at death, mother & & 82.178 & 81.890 & 82.320 & 81.855 \\
\hline & & $(10.271)$ & $(10.208)$ & $(10.311)$ & (10.319) \\
\hline Years of schooling, mother & & 8.528 & 8.639 & 8.509 & 8.695 \\
\hline & & (2.429) & (2.493) & $(2.415)$ & $(2.518)$ \\
\hline Dead by April 2013, father & & 0.789 & 0.727 & 0.811 & 0.723 \\
\hline & & $(0.408)$ & $(0.446)$ & $(0.392)$ & $(0.447)$ \\
\hline Age at death, father & & 76.548 & 76.121 & 76.995 & 76.342 \\
\hline & & $(10.815)$ & (10.916) & $(10.711)$ & $(10.886)$ \\
\hline Predicted age at death, father & & 78.638 & 78.545 & 78.817 & 78.704 \\
\hline & & $(10.592)$ & $(10.344)$ & $(10.521)$ & $(10.261)$ \\
\hline Years of schooling, father & & 9.323 & 9.394 & 9.306 & 9.492 \\
\hline & & (3.098) & (3.103) & (3.125) & (3.158) \\
\hline Observations & $2,828,078$ & 10,837 & 10,837 & 21,206 & 21,206 \\
\hline
\end{tabular}

Note: standard deviations in parentheses. The summary statistics for non-adoptees and the smaller adoptee sample are weighted by the size of the cohorts for non-adoptees. The weighting is done separately for mothers and fathers, meaning that the biological mothers are comparable to the biological and adopting mothers in the 
adoptee samples. Since the biological fathers of adopted children are known only for a smaller sample, these are missing in the larger sample of adoptees. ${ }^{19}$

\subsection{The Association between Biological and Adopting Parent Characteristics}

A concern discussed in relation to the interpretation of the coefficient estimates in Section 2, and indicated as being important in our discussion of the institutions of adoption in Sweden in Section 3.5, is that of selective placement of adoptees. Table 4 illustrates the correlation between adopting and biological parents of adoptees by showing correlation coefficients between years of schooling and predicted age of death for the adoptive and biological parents of the adoptees. The estimates are standardized by birth cohorts.

Table 4. Correlation between biological and adoptive parents (mothers and fathers respectively), standardized by cohort.

\begin{tabular}{lcc}
\hline VARIABLES & Mothers & Fathers \\
& & \\
\hline Years of schooling & 0.1684 & 0.1763 \\
Predicted age at death & 0.0306 & 0.0533
\end{tabular}

Note: $p$-values for significance of all estimates below 0.1 percent.

The correlation for years of schooling is quite similar to the one reported by Björklund et al. (2006) for children in cohorts born 1962-1966. It is well known that adoptees are not randomly assigned to families. The correlation in predicted age of death is positive as well, but much lower. This finding is very important for the purpose of this study, since it suggests that selective placement is less likely to generate biased estimates of the health/mortality correlations using adoption data. However, as these correlations are not zero and because we also investigate the importance of educational attainment, we cannot completely disregard the issue.

\footnotetext{
${ }^{19}$ We have chosen non-adopted children and their parents as the reference category when weighting to be able to display the differences among the different categories in a way that is as transparent as possible. Choosing adoptees as the reference would have made the weighting of parents more difficult as we would not be able to compare the biological and adoptive parents of adoptees internally without including another column. In other parts of the paper when we weight the cohorts to compare non-adoptees and adoptees, we weight non-adoptees (adoptees are used as "reference"). The reason is that there are very few adoptees in each year at the beginning of the period and we are reluctant to increase the weight of the cause of death or diagnoses at hospitalization for this sample.
} 
There are at least two reasons why we would observe a positive correlation for characteristics of biological and adoptive parents. First, this could happen if some adoptions are made by relatives of one of the biological parents. Second, there could be matching on characteristics known to the adoption agency, either because of the demand of parents, or because of a view that an adopted child would be better off in an adoptive family with similar characteristics as the biological parents.

As discussed in Section 3.4, the empirical importance of the first reason - adoptions by relatives - is likely to be very limited since the rule of not allowing people with own biological children to adopt to a large extent precluded parents and siblings of the biological parents from doing that. Nordlöf (2001) estimated these adoptions to be around 1 percent of the total number of adoptions in the Stockholm area. Brandén, Lindahl and Öckert (2015) confirm this conclusion, although their estimate of the share of adoptions by close relatives is slightly higher at 5.4 percent, applying to the whole country. They are also able to eliminate those adopted by close relatives from their sample and find that the correlation in years of schooling between (unrelated) adoptive and biological parents of adoptees remains virtually unchanged.

The second reason, matching, is likely to be a more important mechanism. If this matching is made on characteristics observable in the data (such as educational attainment or health characteristics), we are able to control for this in the estimations. In a sensitivity analysis, we will investigate this further by including more detailed health and education data of the biological (adoptive) parents and see what happens to the estimate for the characteristics of adoptive (biological) parents (a similar test was made in Björklund, Lindahl and Plug, 2006). If we do not see a change, which is what happens (see Section 5.4), we can rule out matching on observable characteristics as affecting our conclusions.

The remaining reason would then be matching on characteristics that are unobservable in the data. Björklund et al. (2006) investigate this issue by deriving the magnitude of the bias (modeled as a combination of selective placement and measurement error), finding evidence that the bias accounts for at most 13 percent of the estimated impact of the adoptive and biological parents' characteristics on adoptees' educational attainment. Given the low correlations in age at death among parents in Table 4, we have no reason to believe that this should be a more severe problem in this setting. Nevertheless, we return to and further examine this issue in Section 5.4. 


\section{Results}

We first present results using mortality as a health outcome of the adopted children. We proceed by showing results for our other two types of health outcomes: hospitalization-based measures for adoptees and the birth outcomes for children of the female adoptees. For each of these outcomes, we study the association with parental mortality and educational attainments.

\subsection{Mortality}

Table 5 shows results from Cox proportional hazard regression models for mortality of individuals born in Sweden between 1940 and 1967 on parental health. We use two measures of parental health. First, the actual age at death for the parent and a dummy variable indicating whether the parent was still alive in 2013 (parents still alive in 2013 are coded as having died at their age in 2013). Second, we use the predicted age at death of the parents. ${ }^{20}$

The first two columns show the results for non-adoptees. The results are strongly significant and indicate that an extra year of life for (one of) the biological parents is associated with a decrease in the risk of death by about one percent for the biological child. For both measures, the association is slightly stronger for the mother's life expectancy than for that of the father.

Columns 3 and 4 show the results for adoptees when we are able to observe information on both adopting parents and Columns 5 and 6 for the extended sample where we also include those for whom we have no information on their biological father. The results for both biological parents' mortality are highly significant and very similar in magnitudes to those reported in the first two columns for the children raised by their biological parent, or even somewhat stronger. An additional year in predicted life expectancy of the biological mother is associated with a 1.4 percent reduction in the mortality risk of the adopted child. The corresponding number for children raised by their biological parents is 1.1. The numbers for biological fathers are similar. None of the estimates for the adopting parents are significantly different from zero - the hazard ratio at one - in any of the samples.

Since we predict age at death for a sizeable part of the parents, we need to worry about measurement error bias leading to downward bias in the estimates presented in Table 5.

\footnotetext{
${ }^{20}$ See Section 3 for a detailed description for how these predictions were obtained.
} 
However, if we only use older cohorts of parents (born prior to 1955), for whom we can observe actual age at death for a much larger fraction of the parents, we obtain almost identical estimates (see Appendix Table A5). Hence, we conclude that measurement error bias is unlikely to impact our results in a way that affects our conclusions. ${ }^{21}$

Table 5. Associations between parental mortality/life expectancy and child mortality

\begin{tabular}{|c|c|c|c|c|c|c|}
\hline & \multicolumn{2}{|c|}{ Non-adoptees } & \multicolumn{2}{|c|}{$\begin{array}{c}\text { Adoptees - Bio father } \\
\text { known }\end{array}$} & \multicolumn{2}{|c|}{$\begin{array}{c}\text { Adoptees - Large } \\
\text { sample }\end{array}$} \\
\hline & (1) & (2) & (3) & (4) & $(5)$ & (6) \\
\hline & Actual & Predicted & Actual & Predicted & Actual & Predicted \\
\hline Age at death, Bio Mother & $\begin{array}{l}0.9916^{* * *} \\
(0.0002)\end{array}$ & $\begin{array}{l}0.9888^{* * *} \\
(0.0002)\end{array}$ & $\begin{array}{l}0.9829^{* * *} \\
(0.0041)\end{array}$ & $\begin{array}{l}0.9861^{* * *} \\
(0.0031)\end{array}$ & $\begin{array}{l}0.9865^{* * *} \\
(0.0028)\end{array}$ & $\begin{array}{l}0.9876^{* * *} \\
(0.0021)\end{array}$ \\
\hline Age at death, Bio Father & $\begin{array}{l}0.9929^{* * *} \\
(0.0002)\end{array}$ & $\begin{array}{l}0.9912^{* * *} \\
(0.0002)\end{array}$ & $\begin{array}{c}0.9872^{* * *} \\
(0.0039)\end{array}$ & $\begin{array}{l}0.9853^{* * *} \\
(0.0031)\end{array}$ & & \\
\hline Alive 2013, Bio Mother & $\begin{array}{l}0.7742^{* * *} \\
(0.0050)\end{array}$ & & $\begin{array}{c}0.8850 \\
(0.0754)\end{array}$ & & $\begin{array}{l}0.8810^{* *} \\
(0.0503)\end{array}$ & \\
\hline Alive 2013, Bio Father & $\begin{array}{c}0.7943^{* * *} \\
(0.0066)\end{array}$ & & $\begin{array}{l}0.7733^{* *} \\
(0.0814)\end{array}$ & & & \\
\hline Age at death, Ad Mother & & & $\begin{array}{c}0.9990 \\
(0.0042)\end{array}$ & $\begin{array}{c}0.9972 \\
(0.0036)\end{array}$ & $\begin{array}{c}0.9989 \\
(0.0027)\end{array}$ & $\begin{array}{c}0.9979 \\
(0.0023)\end{array}$ \\
\hline Age at death, Ad Father & & & $\begin{array}{c}1.0003 \\
(0.0039)\end{array}$ & $\begin{array}{c}1.0010 \\
(0.0036)\end{array}$ & $\begin{array}{c}1.0010 \\
(0.0025)\end{array}$ & $\begin{array}{c}1.0000 \\
(0.0023)\end{array}$ \\
\hline Alive 2013, Ad Mother & & & $\begin{array}{c}0.9016 \\
(0.0987)\end{array}$ & & $\begin{array}{c}0.9694 \\
(0.0731)\end{array}$ & \\
\hline Alive 2013, Ad Father & & & $\begin{array}{c}1.0751 \\
(0.1458)\end{array}$ & & $\begin{array}{c}0.9199 \\
(0.0883)\end{array}$ & \\
\hline P-value joint significance & & & & & & \\
\hline Biological parents & 0.0000 & 0.0000 & 0.0000 & 0.0000 & 0.0000 & 0.0000 \\
\hline Adoptive parents & & & 0.8779 & 0.7055 & 0.8522 & 0.6673 \\
\hline Observations & $2,828,078$ & $2,828,078$ & 10,837 & 10,837 & 21,206 & 21,206 \\
\hline
\end{tabular}

Note: Results from Cox proportional hazard models. Standard errors in parentheses; *** significant at $1 \%$, ** at $5 \%$, * at 10\%. . Each column represents a separate regression and all regressions include indicators for gender and birth cohort of children, and five-year intervals for parental cohorts. Columns (1)-(2) are based on a sample of non-adopted children, columns (3)-(4) on adoptees for whom we have information on all parents, and in columns (5)-(6) we add adoptees with unknown biological fathers. Results in columns (1), (3), and (5) are estimated using observed parental age at death, and an indicator of whether death is censured in the end of our period of study. In columns (2), (4), and (6), we show results using predicted age at death for censured parents

\footnotetext{
${ }^{21}$ For the cohorts of children born prior to 1955, the fraction of parents that are deceased at the end of our observational window are: For the population of non-adoptees, $79.9 \%$ of mothers and $93.0 \%$ of fathers. For the adopted children these fractions are $90.2 \%$ of adoptive mothers, $97.7 \%$ of adoptive fathers, $68.6 \%$ for biological mothers and $74.5 \%$ for biological fathers. Hence, measurement error bias in our estimates is likely to be almost non-existent for adoptive parents for these cohorts. For biological parents, it still likely has an impact, meaning that the positive and statistically significant estimates of the association between biological parent's life expectance and adopted children's mortality risk are slightly underestimated.
} 
In the first column of Table 6, we report the correlation between parental years of education and the longevity of children raised by their biological parents. An additional year of maternal or paternal schooling decreases the risk of dying for own children by about 2.5 percent. Comparing these effects to those reported in Table 5 above, we note that an extra year of schooling has more than twice the effect of an extra year of life expectancy.

A different picture emerges when we consider the set of adoptees in columns (2) and (3). For these children, the education of the biological parents is less significant, while the education of the adoptive mother in particular plays a much more important role. We see that the point estimate suggests that an extra year of education for the adopting mother decreases the mortality probability by 2.9-4.6 percent. The effect for the adopting parents is not significantly different from the corresponding one for parents of children raised by their biological parents, which is reported in column (1).

If we compare the estimates for the biological mother and father of the adopted children, we see that they are now marginally statistically different (which was not the case for parents' health, reported in Table 5). The estimate for years of education for the biological mother is now positive, predicting a higher mortality risk. However, there are two reasons why we do not want to emphasize this result. First, when we consider the results from the larger adoption sample in column (3), there is no evidence of such an adverse effect for biological mothers. Second, we find no supporting evidence for this adverse effect in the other health outcomes reported later in the paper. 
Table 6. Associations between parental years of schooling and child mortality

\begin{tabular}{|c|c|c|c|}
\hline & $\begin{array}{c}\text { (1) } \\
\text { Non-adoptees }\end{array}$ & $\begin{array}{c}\text { (2) } \\
\text { Adoptees - Bio } \\
\text { father known }\end{array}$ & $\begin{array}{c}\text { (3) } \\
\text { Adoptees - Large } \\
\text { sample }\end{array}$ \\
\hline Years of education, Bio Mother & $\begin{array}{l}0.9769^{* * *} \\
(0.0015)\end{array}$ & $\begin{array}{l}1.0453^{*} \\
(0.0243)\end{array}$ & $\begin{array}{c}0.9901 \\
(0.0150)\end{array}$ \\
\hline Years of education, Bio Father & $\begin{array}{c}0.9747^{* * *} \\
(0.0011)\end{array}$ & $\begin{array}{c}0.9887 \\
(0.0180)\end{array}$ & \\
\hline Years of education, Ad Mother & & $\begin{array}{l}0.9536^{* *} \\
(0.0208)\end{array}$ & $\begin{array}{l}0.9707^{* *} \\
(0.0138)\end{array}$ \\
\hline Years of education, Ad Father & & $\begin{array}{c}0.9926 \\
(0.0159)\end{array}$ & $\begin{array}{c}0.9981 \\
(0.0102)\end{array}$ \\
\hline \multicolumn{4}{|l|}{$P$-value joint significance } \\
\hline Biological parents & 0.0000 & 0.1569 & 0.5119 \\
\hline Adoptive parents & & 0.0171 & 0.0456 \\
\hline Observations & $2,828,078$ & 10,837 & 21,206 \\
\hline
\end{tabular}

The hazard rate is likely to be different for women and men, as we know that gender is a strong predictor for longevity. We therefore split the sample by gender and study the associations between child mortality and biological and adoptive parents' longevity and years of schooling. Results are reported in the Appendix (Table A1-2), and show that the overall associations are robust, but also that there are differences between gender groups in the influence of parental characteristics. For male adoptees, longevity of biological fathers is more important than longevity of biological mothers. In contrast, the association between female adoptees and their biological mothers' longevity is stronger. Turning to the role of parental schooling, we still find support for a stronger association within gender groups, although the precision is inferior for adoptees.

To sum up, we find a strong association between the health measures of the biological parents and the mortality of the children. The magnitudes of the point estimates are very similar for those raised with their biological parents and for those raised by adopting parents. We find no significant associations between the health of adopting parents and the mortality of the adopted child. A different picture emerges when we consider educational attainments. We find a significant relation between the educational attainment of the adopting mother and the mortality of the child. We can therefore conclude that the intergenerational association in 
mortality is driven by pre-birth factors, whereas the association between mortality in the child generation and parents' education is driven by post-birth factors.

So far, we have estimated specifications using either parental health or parental education as explanatory variables. This is a reasonable approach, since both of these variables are highly interrelated and since our main focus is on estimating associations. However, by extending the model to include measures of both life expectancy and educational attainments of biological and adopting parents in the same model, we can potentially learn something about mechanisms underlying the observed associations. Is the intergenerational association in mortality driven by the intergenerational transmission of education? Is the finding that pre-birth factors are the driving force in this association due to the fact that we have not adjusted for differences in pre-birth factors related to education? Is the strong association between mortality in the child generation and adoptive parents' education due to not controlling for health related pre-birth factors? An obvious problem with this approach is that it introduces a bias in our estimates by including endogenous regressors (mediating factors) into the model. Hence, these results should be interpreted with caution.

The first column in Table 7 shows that, for the sample of non-adoptees, the inverse effect of parental education is robust to the inclusion of controls for parental health. Hence, the predicted life length of the parents is not a mediating factor in the relationship between educational attainment of parents and children's mortality. This is true also for the results for adoptees shown in Columns 3 and 5. The estimates remain very similar as compared to the specifications with health and educational attainment of parents included separately. Thus, we find that the strong association with the biological parents' health is stable, and that the health of the parents is not a mediating factor in the association between children's mortality and parents' education.

From previous research, we know that there is a strong association between education and health for individuals in the same generation, as well as between parental and child educational attainments. This means that the effect of adopting parents' education on child health can be indirect, going through children's educational attainments (the so-called pathway hypothesis), ${ }^{22}$ rather than direct through influences during childhood and adolescence. Therefore, we also show results in an extended model where we include

\footnotetext{
${ }^{22}$ See e.g. Marmot et al. (2001).
} 
children's education in the specification. The estimates for parental health should now be interpreted as the intergenerational association in health that is not driven by the intergenerational association in education. ${ }^{23}$ Estimates from this specification are shown in columns 2, 4 and 6 in Table 7.

In column 2, for the sample of non-adoptees, we see that when we also include a control for the child's educational attainment, the estimates for parents' health are virtually unchanged, showing that the intergenerational association in mortality is not driven by the intergenerational association in education. Turning to the estimates for parental education, we see that the effect of parental education is wiped out and the coefficient even changes sign. This result supports the pathway hypothesis of no direct effect of parental SES on children's health status as adult health, but only through the children's own educational attainment.

Columns 4 and 6 show the corresponding results for adoptees. The result in these columns differs somewhat for those obtained from the sample of non-adoptees. The estimates for adopting parents’ education are now insignificant. ${ }^{24}$ However, this is most likely due to inferior precision in this set of estimates.

\footnotetext{
${ }^{23}$ See Halphen Boserup et al. (2014) for a discussion of the assumptions underlying this interpretation.

${ }^{24}$ The number of observations is slightly lower in the columns where we control for education of the child since we do not have educational attainment for all children.
} 
Table 7. Associations between parental life expectancy, years of schooling and child mortality

\begin{tabular}{|c|c|c|c|c|c|c|}
\hline \multirow{3}{*}{ Age at death, Bio Mother } & (1) & (2) & (3) & (4) & (5) & (6) \\
\hline & \multicolumn{2}{|c|}{ Non-adoptees } & \multicolumn{2}{|c|}{ Adoptees - Bio father known } & \multicolumn{2}{|c|}{ Adoptees - Large sample } \\
\hline & $\begin{array}{l}0.9893^{* * *} \\
(0.0002)\end{array}$ & $\begin{array}{c}0.9898^{* * *} \\
(0.0002)\end{array}$ & $\begin{array}{c}0.9857^{* * *} \\
(0.0031)\end{array}$ & $\begin{array}{c}0.9851^{* * *} \\
(0.0032)\end{array}$ & $\begin{array}{l}0.9879^{* * *} \\
(0.0021)\end{array}$ & $\begin{array}{l}0.9867^{* * *} \\
(0.0022)\end{array}$ \\
\hline Age at death, Bio Father & $\begin{array}{l}0.9917^{* * *} \\
(0.0002)\end{array}$ & $\begin{array}{l}0.9912^{* * *} \\
(0.0002)\end{array}$ & $\begin{array}{l}0.9854^{* * *} \\
(0.0031)\end{array}$ & $\begin{array}{c}0.9873^{* * *} \\
(0.0033)\end{array}$ & & \\
\hline \multicolumn{3}{|l|}{ Age at death, Ad Mother } & $\begin{array}{c}0.9976 \\
(0.0036)\end{array}$ & $\begin{array}{c}0.9968 \\
(0.0037)\end{array}$ & $\begin{array}{c}0.9982 \\
(0.0023)\end{array}$ & $\begin{array}{c}0.9981 \\
(0.0025)\end{array}$ \\
\hline \multicolumn{3}{|l|}{ Age at death, Ad Father } & $\begin{array}{c}1.0013 \\
(0.0036)\end{array}$ & $\begin{array}{c}1.0000 \\
(0.0037)\end{array}$ & $\begin{array}{c}1.0001 \\
(0.0023)\end{array}$ & $\begin{array}{c}0.9996 \\
(0.0025)\end{array}$ \\
\hline Years of education, Bio Mother & $\begin{array}{l}0.9810^{* * *} \\
(0.0015)\end{array}$ & $\begin{array}{l}1.0053^{* * *} \\
(0.0017)\end{array}$ & $\begin{array}{l}1.0582^{* *} \\
(0.0245)\end{array}$ & $\begin{array}{l}1.0765^{* * *} \\
(0.0265)\end{array}$ & $\begin{array}{c}0.9971 \\
(0.0151)\end{array}$ & $\begin{array}{c}1.0151 \\
(0.0163)\end{array}$ \\
\hline Years of education, Bio Father & $\begin{array}{l}0.9795^{* * *} \\
(0.0011)\end{array}$ & $\begin{array}{l}1.0108^{* * *} \\
(0.0012)\end{array}$ & $\begin{array}{c}0.9978 \\
(0.0182)\end{array}$ & $\begin{array}{c}1.0149 \\
(0.0193)\end{array}$ & & \\
\hline \multicolumn{3}{|l|}{ Years of education, Ad Mother } & $\begin{array}{l}0.9567^{* *} \\
(0.0209)\end{array}$ & $\begin{array}{c}0.9624 \\
(0.0225)\end{array}$ & $\begin{array}{c}0.9731^{*} \\
(0.0139)\end{array}$ & $\begin{array}{c}0.9754 \\
(0.0152)\end{array}$ \\
\hline \multicolumn{3}{|l|}{ Years of education, Ad Father } & $\begin{array}{c}0.9973 \\
(0.0160)\end{array}$ & $\begin{array}{c}1.0170 \\
(0.0174)\end{array}$ & $\begin{array}{c}1.0002 \\
(0.0103)\end{array}$ & $\begin{array}{l}1.0248^{* *} \\
(0.0116)\end{array}$ \\
\hline Years of education, Child & & $\begin{array}{l}0.8997^{* * *} \\
(0.0009)\end{array}$ & & $\begin{array}{l}0.8567^{* * *} \\
(0.0155)\end{array}$ & & $\begin{array}{l}0.8746^{* * *} \\
(0.0103)\end{array}$ \\
\hline \multicolumn{7}{|l|}{$P$-value joint significance } \\
\hline Biological parents & 0.0000 & 0.0000 & 0.0000 & 0.0000 & 0.0000 & 0.0000 \\
\hline Adoptive parents & & & 0.1475 & 0.4582 & 0.2413 & 0.2109 \\
\hline Observations & $2,828,078$ & $2,771,831$ & 10,837 & 10,697 & 21,206 & 20,893 \\
\hline \multicolumn{7}{|c|}{$\begin{array}{l}\text { Note: Results from Cox proportional hazard models. Standard errors in parentheses; }{ }^{* * *} \text { significant at } 1 \%, * * \text { at } \\
5 \% \text {, * at } 10 \% \text {. Each column represents a separate regression and all regressions include indicators for gender } \\
\text { and birth cohort of children, and five-year intervals for parental cohorts. Columns (1)-(2) are based on a sample } \\
\text { of non-adopted children, columns (3)-(4) on adoptees for whom we have information on all parents, and in } \\
\text { columns (5)-(6) we add adoptees with unknown biological fathers. Adding children's years of schooling in } \\
\text { column (2), (4) and (6) reduces the number of observations slightly because we do not have educational } \\
\text { attainment for all children. }\end{array}$} \\
\hline
\end{tabular}

\subsection{Health Measures Based on Hospitalization Data}

Table 8 reports OLS regression results for two additional measures for health of the child generation: Hospitalization and Health index. The construction of both these measures is described in Section 3. Both indices are inversely related to lifetime health. To save space, we only report results from specifications using the predicted age at death for the parents. ${ }^{25}$

Columns 1 and 4 report the results for non-adoptees. As expected, the coefficient estimates for this sample are significantly negative. The relation between the estimates for mothers and fathers is the same as for the results reported for mortality in Table 5. The effects of one additional year of life expectancy for the mother (father), conditional on the other

\footnotetext{
${ }^{25}$ Results from the omitted specifications are available from the authors upon request
} 
parent, are $-0.0046(-0.0038)$ S.D. units for hospitalization. ${ }^{26}$ This is equivalent to effect sizes of about -0.057 for mothers and -0.043 for fathers. Hence, if both biological parents have one S.D. unit higher life expectancy, relative to the mean, their children are expected to have about one-tenth of a S.D. better health. ${ }^{27}$ Hence, we find that the intergenerational transmission of health in the population is positive and non-trivial, although smaller than what is typically found for outcomes such as education and income (see Black and Devereux, 2010). ${ }^{28}$

The results for adoptees - reported in Columns 2, 3, 5 and 6 - are again very similar to the non-adoptees for the biological parents, i.e., qualitatively similar to those reported on mortality. As opposed to the estimates reported for mortality, the measures of the life expectancy of the adopting parents are jointly statistically significantly different from zero for the Hospitalization measure. However, the magnitude of the estimates is still smaller for adoptive parents than for the biological ones.

For the Health index, we see that the adoptive parents are no longer jointly significant. As this measure uses information on both hospitalization and date of death, it is perhaps not surprising that the results are somewhere in between the ones for mortality and hospitalization. ${ }^{29}$

\footnotetext{
${ }^{26}$ Means are around zero for both measures and the standard deviation is 0.124 for the hospitalization measure and 0.016 for the health index for the biological children raised by their biological parents. Hence, multiplying the estimates in columns 1-3 by 8 , and the estimates in columns $4-6$ by 62 , produces effects that are interpretable as the S.D. unit change in poor health from one additional year of life expectancy for one of the parents.

${ }^{27}$ The numbers are slightly lower for the health index, resulting in an effect size from both biological parents having one S.D. unit higher life expectancy of their children being expected to have about 0.07 of a S.D. lower health.

${ }^{28}$ This is in line with the finding in Mazumder (2011) of smaller sibling correlations in health status than for education and family income.

${ }^{29}$ We find that the intergenerational transmission of health in the population is lower than for outcomes such as education and income and driven mainly by pre-birth factors. This finding is consistent with a story where prebirth factors are similarly important for intergenerational mobility of health, education and income, whereas post-birth factors are more important for intergenerational mobility of education and income (Björklund, Lindahl and Plug, 2006).
} 
Table 8. Associations between parental life expectancy and child lifetime health

\begin{tabular}{|c|c|c|c|c|c|c|}
\hline & \multicolumn{3}{|c|}{ Hospitalization } & \multicolumn{3}{|c|}{ Health index } \\
\hline & $\begin{array}{c}(1) \\
\text { Non-adoptees }\end{array}$ & $\begin{array}{c}(2) \\
\text { Adoptees - } \\
\text { Bio father } \\
\text { known }\end{array}$ & $\begin{array}{c}(3) \\
\text { Adoptees - } \\
\text { Large sample }\end{array}$ & $\begin{array}{c}\text { (4) } \\
\text { Non-adoptees }\end{array}$ & $\begin{array}{c}(5) \\
\text { Adoptees - } \\
\text { Bio father } \\
\text { known }\end{array}$ & $\begin{array}{c}(6) \\
\text { Adoptees - } \\
\text { Large sample }\end{array}$ \\
\hline Age at death, Bio Mother & $\begin{array}{l}-0.00057^{* * *} \\
(0.00001)\end{array}$ & $\begin{array}{c}-0.00060^{* * *} \\
(0.00011)\end{array}$ & $\begin{array}{l}-0.00067^{* * *} \\
(0.00008)\end{array}$ & $\begin{array}{l}-0.00005^{* * *} \\
(0.00000)\end{array}$ & $\begin{array}{l}-0.00007^{* * *} \\
(0.00002)\end{array}$ & $\begin{array}{l}-0.00007^{* * *} \\
(0.00001)\end{array}$ \\
\hline Age at death, Bio Father & $\begin{array}{c}-0.00047^{* * *} \\
(0.00001)\end{array}$ & $\begin{array}{c}-0.00034^{* * *} \\
(0.00011)\end{array}$ & & $\begin{array}{c}-0.00004^{* * *} \\
(0.00000)\end{array}$ & $\begin{array}{l}-0.00004^{* *} \\
(0.00002)\end{array}$ & \\
\hline Age at death, Ad Mother & & $\begin{array}{l}-0.00010 \\
(0.00012)\end{array}$ & $\begin{array}{l}-0.00015^{*} \\
(0.00009)\end{array}$ & & $\begin{array}{c}0.00000 \\
(0.00002)\end{array}$ & $\begin{array}{c}-0.00000 \\
(0.00001)\end{array}$ \\
\hline Age at death, Ad Father & & $\begin{array}{c}-0.00034^{* * *} \\
(0.00012)\end{array}$ & $\begin{array}{c}-0.00026^{* * *} \\
(0.00008)\end{array}$ & & $\begin{array}{l}-0.00002 \\
(0.00002)\end{array}$ & $\begin{array}{l}-0.00002^{*} \\
(0.00001)\end{array}$ \\
\hline$P$-value joint significance & & & & & & \\
\hline Biological parents & 0.0000 & 0.0000 & 0.0000 & 0.0000 & 0.0000 & 0.0000 \\
\hline Adoptive parents & & 0.0107 & 0.0021 & & 0.3341 & 0.1805 \\
\hline Observations & $2,802,697$ & 10,798 & 21,059 & $2,802,697$ & 10,798 & 21,059 \\
\hline \multicolumn{7}{|c|}{$\begin{array}{l}\text { Note: Results from OLS regressions. Standard errors in parentheses; *** significant at } 1 \% \text {, ** at } 5 \%, * \text { at } 10 \% \text {. . } \\
\text { Each column represents a separate regression and all regressions include indicators for gender and birth cohort of } \\
\text { children, and five-year intervals for parental cohorts. Columns (1) and (4) are based on a sample of non-adopted } \\
\text { children, columns (2) and (5) on adoptees for whom we have information on all parents, and in columns (3) and } \\
\text { (6) we add adoptees with unknown biological fathers. The dependent variable in columns (1)-(3) is a measure of } \\
\text { hospitalizations, and the dependent variable in columns (4)-(6) is a health index. }\end{array}$} \\
\hline
\end{tabular}

Table 9 shows the corresponding results for parental educational attainments. The results for non-adoptees, shown in columns (1) and (4), reveal a highly significant inverse relation between the two measures of child health and the educational attainments of the parents. Moreover, the results for adoptees in general confirm those obtained for mortality in Table 6. However, as opposed to the previous results, we note that the educational attainments of the biological parents are now jointly significant. The results for the Health index, shown in columns 5 and 6, do, in general, have a lower precision than those obtained for the Hospitalization and show no significant results, although adoptive parents' education is jointly marginally significant in the smaller sample shown in column 5.

In the Appendix (Table A3) we show results from a specification including health and educational attainment of all parents simultaneously. The results from this exercise are very similar to the corresponding specification for mortality. As for mortality, the conditional estimates are not very different from the unconditional ones. When we also control for children's education, the association between child hospitalization and parental education disappears (again supporting the pathway hypothesis). As we point out in the discussion of the mortality results, we interpret the fact that the estimate for biological parents' health is virtually unchanged as indicating that the intergenerational association in health is not explained by the intergenerational association in education. 
Table 9. Associations between parental years of schooling and child lifetime health

\begin{tabular}{|c|c|c|c|c|c|c|}
\hline & \multicolumn{3}{|c|}{ Hospitalization } & \multicolumn{3}{|c|}{ Health index } \\
\hline & $\begin{array}{c}\text { (1) } \\
\text { Non- } \\
\text { adoptees }\end{array}$ & $\begin{array}{c}(2) \\
\text { Adoptees - } \\
\text { Bio father } \\
\text { known }\end{array}$ & $\begin{array}{c}\text { (3) } \\
\text { Adoptees - } \\
\text { Large sample }\end{array}$ & $\begin{array}{c}\text { (4) } \\
\text { Non- } \\
\text { adoptees }\end{array}$ & $\begin{array}{c}\text { (5) } \\
\text { Adoptees - } \\
\text { Bio father } \\
\text { known }\end{array}$ & $\begin{array}{c}\text { (6) } \\
\text { Adoptees - } \\
\text { Large sample }\end{array}$ \\
\hline Years of education, Bio Mother & $\begin{array}{c}-0.00115^{* * *} \\
(0.00003)\end{array}$ & $\begin{array}{l}-0.00102 \\
(0.00069)\end{array}$ & $\begin{array}{c}-0.00175^{* * *} \\
(0.00047)\end{array}$ & $\begin{array}{c}-0.00006^{* * *} \\
(0.00000)\end{array}$ & $\begin{array}{c}0.00006 \\
(0.00010)\end{array}$ & $\begin{array}{c}-0.00008 \\
(0.00006)\end{array}$ \\
\hline Years of education, Bio Father & $\begin{array}{c}-0.00144^{* * *} \\
(0.00003)\end{array}$ & $\begin{array}{c}-0.00152^{* * *} \\
(0.00056)\end{array}$ & & $\begin{array}{c}-0.00009^{* * *} \\
(0.00000)\end{array}$ & $\begin{array}{l}-0.00009 \\
(0.00008)\end{array}$ & \\
\hline Years of education, Ad Mother & & $\begin{array}{l}-0.00104^{*} \\
(0.00058)\end{array}$ & $\begin{array}{c}-0.00082^{* *} \\
(0.00041)\end{array}$ & & $\begin{array}{l}-0.00011 \\
(0.00007)\end{array}$ & $\begin{array}{l}-0.00007 \\
(0.00006)\end{array}$ \\
\hline Years of education, Ad Father & & $\begin{array}{l}-0.00073 \\
(0.00047)\end{array}$ & $\begin{array}{c}-0.00123^{* * *} \\
(0.00032)\end{array}$ & & $\begin{array}{l}-0.00001 \\
(0.00006)\end{array}$ & $\begin{array}{l}-0.00001 \\
(0.00004)\end{array}$ \\
\hline \multicolumn{7}{|l|}{ P-value joint significance } \\
\hline Biological parents & 0.0000 & 0.0035 & 0.0002 & 0.0000 & 0.4638 & 0.1864 \\
\hline Adoptive parents & & 0.0017 & 0.0000 & & 0.1137 & 0.2718 \\
\hline Observations & $2,802,697$ & 10,798 & 21,059 & 2,802,697 & 10,798 & 21,059 \\
\hline \multicolumn{7}{|c|}{$\begin{array}{l}\text { Note: Results from OLS regressions. Standard errors in parentheses; } * * * \text { significant at } 1 \%, * * \text { at } 5 \%, * \text { at } 10 \% \text {. . } \\
\text { Each column represents a separate regression and all regressions include indicators for gender and birth cohort of } \\
\text { children, and five-year intervals for parental cohorts. Columns (1) and (4) are based on a sample of non-adopted } \\
\text { children, columns (2) and (5) on adoptees for whom we have information on all parents, and in columns (3) and } \\
\text { (6) we add adoptees with unknown biological fathers. The dependent variable in columns (1)-(3) is a measure of } \\
\text { hospitalizations, and the dependent variable in columns (4)-(6) is a health index. }\end{array}$} \\
\hline
\end{tabular}

To sum up, the results from the regressions based on hospitalization as a health outcome measure generally support the main results obtained on mortality. The life expectancy of the biological parents has an impact of the same magnitude as the one obtained for children raised by their biological parents and the educational attainments of the adopting parents significantly affect the probability of being hospitalized. However, we also see that the life expectancy of the adopting parents and the educational attainments of the biological parents are significant for our hospitalization measure.

How can the differences in the results for mortality and hospitalization be reconciled? One possible explanation is that these two measures capture different aspects of health and that the channels through which parents' education and health affect these outcomes are different. Hospitalization reflects both objectively poor health and the propensity to consume health services at a given health status. These channels are expected to be counteracting with respect to socioeconomic background. High SES families have better health, but consume more health services conditional on health status. The fact that the adoptive parents' health is associated with hospitalization, but not with mortality, may reflect this distinction between the two health measures.

Another possible explanation of the difference could be that the measures reflect different margins of the health distribution. Hospitalization and the Health index are measures that vary over the whole distribution of health status (as almost everybody has been to the 
hospital at least once) whereas only roughly 7-8 percent (of those in the child generation) have died in our sampled period. Thus, the variation in our mortality measure is driven by those who died at relatively early ages.

To check if this can explain the difference in the results, we split the sample into those birth cohorts born prior to 1955 (11.7\% of the children in this sample have died) and those born 1955 and later (4.7 \% have died). Estimates are shown in Appendix Tables A5 through A7. The results reveal some evidence suggesting that the results for Hospitalization in the older sample are indeed qualitatively more similar to those for mortality. For instance, the Age of death for adoptive parents and Years of schooling for biological parents are not jointly significant in the sample born before 1955.

\subsection{Birth Outcomes}

As described in Section 4, the mother's health is reflected in the birth weights of her children. Perhaps even more importantly, weight at birth is a good predictor of adult life health and labor market outcomes. This motivates our use of birth weight of the children of the female adoptees as a proxy for the health of these women and as an additional measure of the intergenerational transmission of health going into the third generation. An important caveat is that selection into giving birth is likely driven by maternal health status, so that healthier women are more likely to deliver live children. That is why we expect that our estimates are biased downwards.

Panel A in Table 10 shows results from intergenerational regressions where we use two measures of the birth weight of the first-born child as a health measure of the mother: the probability of low birth weight $(<2,500 \mathrm{gr})$ and actual (continuous) birth weight for the first born child. Panel B shows the results when we instead use the APGAR at five minutes below 10 and the continuous measure of the APGAR score as health measures. Since we have to restrict the sample to females only for these regressions, the sample sizes are about halved as compared to the regressions shown in the previous tables.

We find highly significant positive effects of the longevity of both biological parents on the birth weight of their grandchildren in the sample of non-adoptees. ${ }^{30}$ For adoptees, the

\footnotetext{
${ }^{30}$ This finding relates to a small but growing literature on multigenerational associations, although estimates of the transmission of health across multiple generations are almost absent in the literature (two exceptions are Johnston et al., 2013, and Piraino et al., 2014). Although birth weight obviously is a non-perfect indicator of
} 
significant effect of the longevity of the biological parents remains in both samples and in three out of four birth outcome measures. For the two measures based on the APGAR score, there is also a significant effect for the longevity measure for the adopting mother.

Table 10. Associations between parental mortality and firstborn grandchild's health at birth

\begin{tabular}{|c|c|c|c|c|c|c|}
\hline & $\begin{array}{c}\text { (1) } \\
\text { Non-adoptees }\end{array}$ & $\begin{array}{c}(2) \\
\text { Adoptees - Bio } \\
\text { father known }\end{array}$ & $\begin{array}{c}3) \\
\text { Adoptees - } \\
\text { Large sample }\end{array}$ & $\begin{array}{c}\text { (4) } \\
\text { Non-adoptees }\end{array}$ & $\begin{array}{c}\text { (5) } \\
\text { Adoptees - Bio } \\
\text { father known }\end{array}$ & $\begin{array}{c}\text { (6) } \\
\text { Adoptees - } \\
\text { Large sample } \\
\end{array}$ \\
\hline Panel A & \multicolumn{3}{|c|}{ Low birth weight $<2,500 \mathrm{~g}$} & \multicolumn{3}{|c|}{ Birth weight } \\
\hline Age at death, Bio Mother & $\begin{array}{l}-0.00018^{* * *} \\
(0.00002)\end{array}$ & $\begin{array}{l}-0.00050 \\
(0.00036)\end{array}$ & $\begin{array}{c}-0.00030 \\
(0.00026)\end{array}$ & $\begin{array}{l}0.65756^{* * *} \\
(0.06239)\end{array}$ & $\begin{array}{l}1.79747^{* *} \\
(0.82784)\end{array}$ & $\begin{array}{l}1.37878^{* *} \\
(0.62894)\end{array}$ \\
\hline Age at death, Bio Father & $\begin{array}{l}-0.00026^{* * *} \\
(0.00002)\end{array}$ & $\begin{array}{l}-0.00042 \\
(0.00038)\end{array}$ & & $\begin{array}{l}1.18192^{* * *} \\
(0.05698)\end{array}$ & $\begin{array}{l}-0.24153 \\
(0.88269)\end{array}$ & \\
\hline Age at death, Ad Mother & & $\begin{array}{l}-0.00002 \\
(0.00042)\end{array}$ & $\begin{array}{l}-0.00007 \\
(0.00030)\end{array}$ & & $\begin{array}{c}0.41496 \\
(1.00028)\end{array}$ & $\begin{array}{c}0.91839 \\
(0.74060)\end{array}$ \\
\hline Age at death, Ad Father & & $\begin{array}{c}0.00063^{*} \\
(0.00037)\end{array}$ & $\begin{array}{c}0.00049^{*} \\
(0.00028)\end{array}$ & & $\begin{array}{l}-1.69671^{*} \\
(0.93997)\end{array}$ & $\begin{array}{l}-0.85651 \\
(0.69848)\end{array}$ \\
\hline $\begin{array}{l}\text { P-value joint significance } \\
\text { Biological parents } \\
\text { Adoptive parents }\end{array}$ & 0.0000 & $\begin{array}{l}0.2184 \\
0.2409\end{array}$ & $\begin{array}{l}0.2615 \\
0.2141\end{array}$ & 0.0000 & $\begin{array}{l}0.0933 \\
0.1773\end{array}$ & $\begin{array}{l}0.0284 \\
0.2209\end{array}$ \\
\hline $\begin{array}{l}\text { Mean } \\
\text { Observations }\end{array}$ & $\begin{array}{c}0.052 \\
790,124 \\
\end{array}$ & $\begin{array}{l}0.066 \\
3,469 \\
\end{array}$ & $\begin{array}{l}0.063 \\
6,399 \\
\end{array}$ & $\begin{array}{c}3417.149 \\
790,124 \\
\end{array}$ & $\begin{array}{c}3392.872 \\
3,469 \\
\end{array}$ & $\begin{array}{c}3401.001 \\
6,399 \\
\end{array}$ \\
\hline Panel B & \multicolumn{3}{|c|}{$A P G A R 5<10$} & \multicolumn{3}{|c|}{ APGAR5 } \\
\hline Age at death, Bio Mother & $\begin{array}{c}-0.00041^{* * *} \\
(0.00005)\end{array}$ & $\begin{array}{l}-0.00147^{* *} \\
(0.00067)\end{array}$ & $\begin{array}{l}-0.00116^{* *} \\
(0.00051)\end{array}$ & $\begin{array}{l}0.00064^{* * * *} \\
(0.00011)\end{array}$ & $\begin{array}{l}0.00533^{* * * *} \\
(0.00183)\end{array}$ & $\begin{array}{l}0.00310^{* *} \\
(0.00129)\end{array}$ \\
\hline Age at death, Bio Father & $\begin{array}{c}-0.00044^{* * *} \\
(0.00005)\end{array}$ & $\begin{array}{c}0.00047 \\
(0.00074)\end{array}$ & & $\begin{array}{l}0.00074^{* * * *} \\
(0.00010)\end{array}$ & $\begin{array}{l}-0.00185 \\
(0.00145)\end{array}$ & \\
\hline Age at death, Ad Mother & & $\begin{array}{l}-0.00218^{* *} \\
(0.00085)\end{array}$ & $\begin{array}{l}-0.00020 \\
(0.00062)\end{array}$ & & $\begin{array}{l}0.00466^{* * *} \\
(0.00179)\end{array}$ & $\begin{array}{c}0.00120 \\
(0.00127)\end{array}$ \\
\hline Age at death, Ad Father & & $\begin{array}{c}0.00014 \\
(0.00081)\end{array}$ & $\begin{array}{c}0.00062 \\
(0.00060)\end{array}$ & & $\begin{array}{l}-0.00110 \\
(0.00164)\end{array}$ & $\begin{array}{l}-0.00135 \\
(0.00129)\end{array}$ \\
\hline $\begin{array}{l}P \text {-value joint significance } \\
\text { Biological parents } \\
\text { Adoptive parents }\end{array}$ & 0.0000 & $\begin{array}{l}0.0741 \\
0.0377\end{array}$ & $\begin{array}{l}0.0238 \\
0.5556\end{array}$ & 0.0000 & $\begin{array}{l}0.0081 \\
0.0248\end{array}$ & $\begin{array}{l}0.0159 \\
0.3602\end{array}$ \\
\hline $\begin{array}{l}\text { Mean } \\
\text { Observations }\end{array}$ & $\begin{array}{c}0.336 \\
715,669 \\
\end{array}$ & $\begin{array}{l}0.343 \\
3,154 \\
\end{array}$ & $\begin{array}{l}0.344 \\
5,764\end{array}$ & $\begin{array}{c}9.526 \\
715,669 \\
\end{array}$ & $\begin{array}{l}9.510 \\
3,154 \\
\end{array}$ & $\begin{array}{l}9.492 \\
5,764\end{array}$ \\
\hline $\begin{array}{l}\text { Note: Results from } \mathrm{O} \\
\text { Each column represer } \\
\text { children, and five-yea } \\
\text { children, columns (2) } \\
\text { (6) we add adoptees } \\
\text { B is binary. The dep } \\
\text { Panel B, the APGAR }\end{array}$ & $\begin{array}{l}\text { regressions. } \\
\text { separate re } \\
\text { tervals for p } \\
\text { (5) on ado } \\
\text { unknown b } \\
\text { ent variable } \\
\text { sure at five }\end{array}$ & $\begin{array}{l}\text { andard errors } \\
\text { ssion and all } \\
\text { ental cohorts. } \\
\text { es for whom } \\
\text { ogical fathers } \\
\text { columns (4)- } \\
\text { nutes ranges }\end{array}$ & $\begin{array}{l}\text { parenthes } \\
\text { ressions in } \\
\text { lumns (1) } \\
\text { have infol } \\
\text { he depend } \\
\text { in Panel } \\
0-10 \text {. }\end{array}$ & $\begin{array}{l}* * \text { signific } \\
\text { e indicator } \\
\text { (4) are bas } \\
\text { ion on all } \\
\text { ariable in } \\
\text { birth wei }\end{array}$ & $\begin{array}{l}\text { at } 1 \%, * * \text { at } \\
\text { gender and } \\
\text { o a sample } \\
\text { ats, and in c } \\
\text { mns (1)-(3) } \\
\text { measured in }\end{array}$ & $\begin{array}{l}\text { * * at } 10 \% . \\
\text { th cohort of } \\
\text { lon-adopted } \\
\text { mns (3) and } \\
\text { Panel A and } \\
\text { ams, and in }\end{array}$ \\
\hline
\end{tabular}

Table 11 shows associations between parental educational attainments and grandchildren's birth outcomes. Once more, Panel A shows the results for the two measures based on birth weight and Panel B the ones on APGAR scores. The educational attainment of the biological parents has a significant effect on the health endowment at birth of

adult health it is known to causally impact many adult outcomes including height (see Black, Devereux and Salvanes, 2007). 
grandchildren for all four measures among no-adoptees. An extra year of education among biological mothers is associated with a reduction in the probability of a biological grandchild of low-birth-weight by 1.3 percent (1.6 for the biological father) and increasing the actual birth weight by 4 grams (3 grams for the biological grandfather).

For adoptees, the results in Table 11 are in general too imprecise to generate any significant results. However, the educational attainment of the adopting parents is marginally significant (p-values 6.4 and 8.6 percent) for the two measures based on birth weight in the large adoptee sample.

Table 11. Associations between parental years of schooling and firstborn grandchild's health at birth

\begin{tabular}{|c|c|c|c|c|c|c|}
\hline & $\begin{array}{c}(1) \\
\text { Non-adoptees }\end{array}$ & $\begin{array}{c}(2) \\
\text { Adoptees - } \\
\text { Bio father } \\
\text { known }\end{array}$ & $\begin{array}{c}\text { (3) } \\
\text { Adoptees - } \\
\text { Large sample }\end{array}$ & $\begin{array}{c}\text { (4) } \\
\text { Non-adoptees }\end{array}$ & $\begin{array}{c}\text { (5) } \\
\text { Adoptees - } \\
\text { Bio father } \\
\text { known }\end{array}$ & $\begin{array}{c}(6) \\
\text { Adoptees - } \\
\text { Large sample }\end{array}$ \\
\hline Panel A & \multicolumn{3}{|c|}{ Low birth weight $<2,500 \mathrm{~g}$} & \multicolumn{3}{|c|}{ Birth weight } \\
\hline Years of education, Bio Mother & $\begin{array}{c}-0.00068^{* * * *} \\
(0.00013)\end{array}$ & $\begin{array}{c}0.00213 \\
(0.00241)\end{array}$ & $\begin{array}{c}0.00199 \\
(0.00171)\end{array}$ & $\begin{array}{l}4.08262^{* * *} \\
(0.33498)\end{array}$ & $\begin{array}{c}8.01955 \\
(6.09612)\end{array}$ & $\begin{array}{c}4.87120 \\
(4.14228)\end{array}$ \\
\hline Years of education, Bio Father & $\begin{array}{c}-0.00081^{* * *} \\
(0.00010)\end{array}$ & $\begin{array}{l}-0.00100 \\
(0.00208)\end{array}$ & & $\begin{array}{c}2.81047^{* * *} \\
(0.26578)\end{array}$ & $\begin{array}{l}-4.82113 \\
(5.07571)\end{array}$ & \\
\hline Years of education, Ad Mother & & $\begin{array}{l}-0.00067 \\
(0.00201)\end{array}$ & $\begin{array}{l}-0.00054 \\
(0.00138)\end{array}$ & & $\begin{array}{c}0.68611 \\
(4.91057)\end{array}$ & $\begin{array}{l}-4.01067 \\
(3.48883)\end{array}$ \\
\hline Years of education, Ad Father & & $\begin{array}{l}-0.00155 \\
(0.00156)\end{array}$ & $\begin{array}{l}-0.00194^{*} \\
(0.00111)\end{array}$ & & $\begin{array}{c}5.27417 \\
(3.84956)\end{array}$ & $\begin{array}{l}6.18421^{* *} \\
(2.79315)\end{array}$ \\
\hline $\begin{array}{l}\text { P-value joint significance } \\
\text { Biological parents } \\
\text { Adoptive parents }\end{array}$ & 0.0000 & $\begin{array}{l}0.6354 \\
0.3773\end{array}$ & $\begin{array}{l}0.2441 \\
0.0641\end{array}$ & 0.0000 & $\begin{array}{l}0.3173 \\
0.2447\end{array}$ & $\begin{array}{l}0.2397 \\
0.0863\end{array}$ \\
\hline $\begin{array}{l}\text { Mean } \\
\text { Observations }\end{array}$ & $\begin{array}{c}0.052 \\
790,128 \\
\end{array}$ & $\begin{array}{l}0.066 \\
3,469 \\
\end{array}$ & $\begin{array}{l}0.063 \\
6,399 \\
\end{array}$ & $\begin{array}{c}3417.149 \\
790,128 \\
\end{array}$ & $\begin{array}{c}3392.872 \\
3,469 \\
\end{array}$ & $\begin{array}{c}3401.001 \\
6,399 \\
\end{array}$ \\
\hline Panel B & \multicolumn{3}{|c|}{$A P G A R 5<10$} & \multicolumn{3}{|c|}{ APGAR5 } \\
\hline Years of education, Bio Mother & $\begin{array}{c}-0.00295^{* * *} \\
(0.00028)\end{array}$ & $\begin{array}{l}-0.00259 \\
(0.00494)\end{array}$ & $\begin{array}{l}-0.00369 \\
(0.00344)\end{array}$ & $\begin{array}{l}0.00390^{* * *} \\
(0.00057)\end{array}$ & $\begin{array}{c}0.00743 \\
(0.00930)\end{array}$ & $\begin{array}{c}0.00982 \\
(0.00642)\end{array}$ \\
\hline Years of education, Bio Father & $\begin{array}{c}-0.00272^{* * *} \\
(0.00023)\end{array}$ & $\begin{array}{l}-0.00189 \\
(0.00420)\end{array}$ & & $\begin{array}{l}0.00325^{* * *} \\
(0.00047)\end{array}$ & $\begin{array}{c}0.00584 \\
(0.00848)\end{array}$ & \\
\hline Years of education, Ad Mother & & $\begin{array}{l}-0.00052 \\
(0.00407)\end{array}$ & $\begin{array}{c}-0.00391 \\
(0.00299)\end{array}$ & & $\begin{array}{c}-0.01258 \\
(0.00949)\end{array}$ & $\begin{array}{c}-0.00252 \\
(0.00635)\end{array}$ \\
\hline Years of education, Ad Father & & $\begin{array}{l}-0.00298 \\
(0.00323)\end{array}$ & $\begin{array}{l}-0.00126 \\
(0.00239)\end{array}$ & & $\begin{array}{c}0.01029 \\
(0.00647)\end{array}$ & $\begin{array}{c}0.00739 \\
(0.00456)\end{array}$ \\
\hline $\begin{array}{l}\text { P-value joint significance } \\
\text { Biological parents } \\
\text { Adoptive parents }\end{array}$ & 0.0000 & $\begin{array}{l}0.7442 \\
0.4992\end{array}$ & $\begin{array}{l}0.2832 \\
0.1397\end{array}$ & 0.0000 & $\begin{array}{l}0.5284 \\
0.2410\end{array}$ & $\begin{array}{l}0.1261 \\
0.2422\end{array}$ \\
\hline $\begin{array}{l}\text { Mean } \\
\text { Observations }\end{array}$ & $\begin{array}{c}0.336 \\
715,672\end{array}$ & $\begin{array}{l}0.343 \\
3,154\end{array}$ & $\begin{array}{l}0.344 \\
5,764\end{array}$ & $\begin{array}{c}9.526 \\
715,672\end{array}$ & $\begin{array}{l}9.510 \\
3,154\end{array}$ & $\begin{array}{l}9.492 \\
5,764\end{array}$ \\
\hline
\end{tabular}

Note: Results from OLS regressions. Standard errors in parentheses; *** significant at 1\%, ** at 5\%, $*$ at $10 \%$. Each column represents a separate regression and all regressions include indicators for gender and birth cohort of children, and five-year intervals for parental cohorts. Columns (1) and (4) are based on a sample of non-adopted children, columns (2) and (5) on adoptees for whom we have information on all parents, and in columns (3) and (6) we add adoptees with unknown biological fathers. The dependent variable in columns (1)-(3) in Panel A and $\mathrm{B}$ is binary. The dependent variable in columns (4)-(6) in Panel A is birth weight measured in grams, and in Panel $\mathrm{B}$, the APGAR measure at five minutes ranges from 0-10. 
To summarize, the results obtained for the birth outcome measures, just as those obtained for the hospitalization measures, in general support those obtained for mortality. The biological parents have a strong effect on the birth weight measure and the two measures based on the APGAR score; the adopting parents' educational attainments significantly affect the two measures based on birth weight at the 10 percent level. It is also notable that the transmission of health can span at least three generations.

\subsection{Sensitivity Analyses}

5.4.1 Parameter Robustness and the Altonji-Elder-Taber Test

As we described in Section 2, our strategy to identify the influence of pre- and post-birth factors on adult health depends on the assumption that the pre-birth parental characteristics are unrelated to the post-birth parental characteristics. More specifically, conditional on the observed parental characteristics, we assume that unobservable characteristics of the biological parents are uncorrelated with those of the adopting parents. A simple, and informal, way of testing this assumption empirically is to include and exclude the observable parental characteristics to check the stability of the coefficient estimates of main interest.

Table 12 reports results from a robustness check for the two key results obtained in Section 5.1. Panel A shows the results for the life expectancy and Panel B those for educational attainments. Column 1 shows the results for the biological mother when we include no other parental controls except indicators for the birth cohort of the biological mother and columns 2 and 3 report the results when we successively add variables for the observable characteristics of the adopting parents. Column 4 shows the results for the adopting parents when we only include indicators for year of birth of the adopting mother in the model. Columns 5 and 6 show the results when we successively add variables measuring the characteristics of the biological mother.

The estimates show that the key results - the estimates for the variables Age at death of the biological mother in Panel A and Years of schooling of the adopting mother - are both remarkably robust with respect to different specifications. They also show that the small and statistically insignificant estimates for the Age at death of the adopting mother and the Educational attainments of the biological mother are very stable with respect to different specifications. 
Table 12. Sensitivity analyses of mortality among adoptees.

\begin{tabular}{|c|c|c|c|c|c|c|}
\hline & (1) & (2) & (3) & (4) & (5) & (6) \\
\hline \multicolumn{7}{|l|}{ Panel A: Parental life expectancy } \\
\hline Age at death, Bio Mother & $\begin{array}{c}0.9877^{* * *} \\
(0.0021)\end{array}$ & $\begin{array}{c}0.9879^{* * *} \\
(0.0021)\end{array}$ & $\begin{array}{c}0.9878^{* * *} \\
(0.0021)\end{array}$ & & $\begin{array}{c}0.9877^{* * *} \\
(0.0021)\end{array}$ & $\begin{array}{c}0.9853^{* * *} \\
(0.0031)\end{array}$ \\
\hline Age at death, Ad Mother & & $\begin{array}{c}0.9982 \\
(0.0023)\end{array}$ & $\begin{array}{c}0.9973 \\
(0.0030)\end{array}$ & $\begin{array}{c}0.9973 \\
(0.0023)\end{array}$ & $\begin{array}{c}0.9979 \\
(0.0023)\end{array}$ & $\begin{array}{c}0.9979 \\
(0.0023)\end{array}$ \\
\hline Age at death, Ad Father & & $\begin{array}{c}1.0001 \\
(0.0023)\end{array}$ & $\begin{array}{c}0.9993 \\
(0.0027)\end{array}$ & $\begin{array}{c}0.9995 \\
(0.0023)\end{array}$ & $\begin{array}{c}1.0001 \\
(0.0023)\end{array}$ & $\begin{array}{c}0.9998 \\
(0.0023)\end{array}$ \\
\hline Years of education, Ad Mother & & $\begin{array}{c}0.9729^{*} \\
(0.0138)\end{array}$ & $\begin{array}{l}0.9706^{* *} \\
(0.0139)\end{array}$ & & & \\
\hline Years of education, Ad Father & & $\begin{array}{c}1.0000 \\
(0.0102)\end{array}$ & $\begin{array}{c}0.9973 \\
(0.0104)\end{array}$ & & & \\
\hline Years of education, Bio Mother & & & & & $\begin{array}{c}0.9924 \\
(0.0147)\end{array}$ & $\begin{array}{c}0.9926 \\
(0.0149)\end{array}$ \\
\hline Cohorts, Bio mother & Yes & Yes & Yes & No & Yes & Yes \\
\hline Cohorts, Ad parents & No & Yes & Yes & Yes & Yes & Yes \\
\hline Cause of death, Bio mother & No & No & No & No & No & Yes \\
\hline Municipality, Bio mother & No & No & No & No & No & Yes \\
\hline Cause of death, Ad parents & No & No & Yes & No & No & No \\
\hline Municipality, Ad parents & No & No & Yes & No & No & No \\
\hline Observations & 21,206 & 21,206 & 21,206 & 21,206 & 21,206 & 21,206 \\
\hline \multicolumn{7}{|c|}{ Panel B: Parental years of schooling } \\
\hline Years of education, Bio Mother & $\begin{array}{c}0.9841 \\
(0.0145)\end{array}$ & $\begin{array}{c}0.9902 \\
(0.0150)\end{array}$ & $\begin{array}{c}0.9892 \\
(0.0151)\end{array}$ & & $\begin{array}{c}0.9971 \\
(0.0151)\end{array}$ & $\begin{array}{c}0.9975 \\
(0.0152)\end{array}$ \\
\hline Years of education, Ad Mother & & $\begin{array}{l}0.9714^{* *} \\
(0.0138)\end{array}$ & $\begin{array}{l}0.9690^{* *} \\
(0.0140)\end{array}$ & $\begin{array}{l}0.9703^{* *} \\
(0.0137)\end{array}$ & $\begin{array}{l}0.9726^{*} \\
(0.0138)\end{array}$ & $\begin{array}{c}0.9735^{*} \\
(0.0139)\end{array}$ \\
\hline Years of education, Ad Father & & $\begin{array}{c}0.9983 \\
(0.0103)\end{array}$ & $\begin{array}{c}0.9959 \\
(0.0104)\end{array}$ & $\begin{array}{c}0.9969 \\
(0.0101)\end{array}$ & $\begin{array}{c}1.0002 \\
(0.0103)\end{array}$ & $\begin{array}{c}0.9984 \\
(0.0103)\end{array}$ \\
\hline Age at death, Ad Mother & & $\begin{array}{c}0.9977 \\
(0.0023)\end{array}$ & $\begin{array}{c}0.9967 \\
(0.0030)\end{array}$ & & & \\
\hline Age at death, Ad Father & & $\begin{array}{c}0.9996 \\
(0.0023)\end{array}$ & $\begin{array}{c}0.9987 \\
(0.0027)\end{array}$ & & & \\
\hline Age at death, Bio Mother & & & & & $\begin{array}{c}0.9879^{* * *} \\
(0.0021)\end{array}$ & $\begin{array}{c}0.9853^{* * *} \\
(0.0031)\end{array}$ \\
\hline Cohorts, Bio mother & Yes & Yes & Yes & No & Yes & Yes \\
\hline Cohorts, Ad parents & No & Yes & Yes & Yes & Yes & Yes \\
\hline Cause of death, Bio mother & No & No & No & No & No & Yes \\
\hline Municipality, Bio mother & No & No & No & No & No & Yes \\
\hline Cause of death, Ad parents & No & No & Yes & No & No & No \\
\hline Municipality, Ad parents & No & No & Yes & No & No & No \\
\hline Observations & 21,206 & 21,206 & 21,206 & 21,206 & 21,206 & 21,206 \\
\hline
\end{tabular}

Note: Results from Cox proportional hazard models using the large sample of adoptees. Standard errors in parentheses; ${ }^{* * *}$ significant at $1 \%,{ }^{* *}$ at $5 \%, *$ at $10 \%$. Each column represents a separate regression and all regressions include indicators for gender and birth cohort of children. Each column is adding parental characteristics.

Altonji et al. (2005) suggest a framework for measuring the potential effect of an omitted variable bias relative to that avoided by the included confounders. This framework requires that the three assumptions stated in their paper are fulfilled. Most importantly, it requires that the included confounders are "randomly selected" from a larger pool of possible 
confounders. ${ }^{31}$ Building on this framework, Bellows and Miguel (2009) show that the ratio $\frac{\widehat{\alpha}_{O L S, C}}{\widehat{\alpha}_{O L S, N C}-\widehat{\alpha}_{O L S, C}}$, where $\hat{\alpha}_{O L S, C}$ is the coefficient estimate when confounders are included in the specification and $\hat{\alpha}_{O L S, N C}$ is the coefficient estimate when confounders are not included, measures how much the omitted variables must affect the key estimates, relative to the included confounders, in order to "explain away” these results.

To use this measure, we need to obtain OLS estimates corresponding to the Cox proportional hazard model results shown in Table 12. For this purpose, we estimate a linear probability model with an indicator variable that equals one if the individual has died before the end of the period we are able to observe in the data as the dependent variable. In the model with no confounders, we only include indicators for year of birth for the adopted child along with the variable under study and cohort controls (corresponding to columns 1 and 4 in Table 12). In the model with confounders, we include all variables included in the specifications corresponding to Columns 3 and 6 in Table 12, respectively. The results from this linear probability model are presented in Appendix Table A10.

In the model where we estimate the association with the age at death of the biological mother, we get an estimate of -0.00087 (s.e. 0.00016 ) in the model with no confounders and 0.00086 (s.e. 0.00016) when confounders are included. The corresponding estimates for the adopting mothers' years of schooling are -0.00183 (s.e. 0.00065 ) and -0.00210 (s.e. 0.00067 ), respectively. These estimates give a value of 86.0 for the ratio corresponding to the age at death of the biological mother and 7.8 for the years of schooling of the adopting mother.

Given the very high quality of the confounders that we are able to use in the regression, it is very unlikely that the unobservables would be 8.0 times stronger than the included ones. As a comparison, we note that Altonji et al. (2005) famously rejected the possibility that unobservable characteristics could account for 3.55 times what the included confounders make up for in the context of the effect of Catholic schools on the probability of high school graduation.

\footnotetext{
31 ”Randomly” should be interpreted as an approximation.
} 


\subsubsection{Is there any Evidence of “Nature-Nurture Interactions”?}

An advantage with the regression-based approach to decomposing pre- and post-birth associations is that the model can very easily be extended to allow for interactions between pre- and post-birth characteristics ("nature-nurture interactions"). This is simply done by adding interaction terms between adoptive and biological parents' characteristics. The results are reported in Appendix Table A11 for child's mortality, hospitalization and health index. In Columns 1, 3 and 5 we interact the life expectancy of the adoptive parents with the life expectancy of the biological mother and in columns 2, 4 and 6 interact years of schooling of the adoptive parents with years of schooling of the biological mother. All models also include main effects.

It is evident that interaction effects are largely non-existent. Only one interaction estimate, out of 12 , is statistically significant. In the bottom row, we report the p-value of a test of the interaction effects being jointly zero in each of the models. In column 3 we are close to rejecting no interaction effects, but since both interaction effects have different signs (and none is significant), we do not make too much out of this. We also investigate whether there were “cross-interaction” between parents' life expectancy and schooling, by including 4 additional interaction terms in a model with main effects for both life expectancy and years of schooling for the parents, finding no evidence of such interaction effects ( $p$-value $=0.58$ : not shown here).

\subsubsection{Adoptees that Move from their Municipality of Birth}

A concern discussed in Section 2 is that the adoptee might still maintain significant contact with the biological parents even after adoption and thus, the characteristics of the biological parents would have effects above and beyond the in utero period. A related concern is that the biological parents may have pre-adoption contact with the adopting parents and are thereby able to intervene in the adoption process.

One way of limiting the effect of this concern is to restrict the sample to only include those adoptees who move out from their municipality of birth after the adoption. The results from Cox proportional hazard models on a sample restricted to movers are presented in Appendix table A12. As is evident from these results, the estimates are very robust to this sample restriction and the key results are still highly significant. 


\subsubsection{First Born Adoptees}

In the final sensitivity analysis, we restrict the sample to include first born adoptees only. As discussed in Section 2, it is more likely that first-born children are adopted away simply because they were not planned by their biological parents and they are less likely to have any contact with their biological parents. The Cox proportional hazard estimates on this sample are reported in Appendix table A13. Once more, it is apparent that the main results are remarkably robust.

\section{Discussion and Conclusions}

We find that the life expectancy of the biological parents and the educational attainment of the adopting parents are significantly associated with the mortality of the adopted children. These results are supported by findings on the health measures of adoptees based on hospitalization as well as the birth outcomes of their children. There is a statistically significant, but fairly small, positive intergenerational association in health in the population. For instance, regressing hospitalization of the child on life expectance for both biological parents, we find effect sizes of about -0.057 for mothers and -0.043 for fathers. The implication is that, if both biological parents have one S.D. unit higher life expectancy, relative to the mean, their children are expected to have about one-tenth of a S.D. better health.

The association between the health of the biological mother and the health of the adopted child stands out as the strongest and most robust one across different measures of child health. The magnitudes of the coefficients are in general very similar to what we obtain for the children raised by their biological parents. The second main result is that the educational attainment of the adopting mother is related to the mortality of the adopted child. Once more, the magnitude of the estimate is quite similar to the one obtained on the sample of non-adoptees for the biological mother. To our knowledge, this result is new. It is important since it speaks to the literature on the relation between parental resources and the formation of child health.

Although we find that there is a significant correlation between observable characteristics of the biological and the adopting parents, it is unlikely that the correlation between unobservable characteristics of the biological and the adopting parents make up for 
our two main results mentioned above. Our sensitivity analysis shows that the results are remarkably robust with respect to inclusion and exclusion of confounding parental characteristics as well as changes in the definition of the sample. The results from the AltonjiElder-Taber analysis suggest that the effect of the unobserved characteristics needs to be 44.6 and 8.0 times as strong as the included parental characteristics in order to explain away the associations for the biological mother's age of death and the adopting mother's education, respectively, which is very unlikely.

The relation between the adopting parents' educational attainments and the mortality of the child can be attributed to, for example, more parental resources in the formative years of the child's health. Alternatively, parents' educational attainment may be important for the adopted child's own educational attainment, which, in turn, may affect his or her health. Our extended analysis when we include the adopted child's own educational attainment in the model suggests that the latter mechanism may be very important. However, since it relies on a model with endogenous regressors included, we interpret these finding as no more than suggestive. More conclusive evidence would require sources of exogenous variation in educational attainments. This important research question is left to further research. 


\section{References}

Allmänna barnhuset (1955), Adoption. Handbook for social workers and authorities responsible for adoption issues. Stockholm.

Allmänna barnhuset (1969) Adoption. Handbook for social workers and authorities responsible for adoption issues. Stockholm.

Almond, D. and J. Currie (2011) "Human capital development before age five" in David Card and Orley Ashenfelter (eds.) Handbook of Labor Economics, 4, 1315-1486.

Altonji, J. G., T. E. Elder, and C. R. Taber (2005) "Selection on Observed and Unobserved Variables: Assessing the Effectiveness of Catholic Schools” Journal of Political Economy 113(1), 151-184.

Bhalotra, S. and S. Rawlings (2013) "Gradients of the Intergenerational Transmission of Health in Developing Countries” Review of Economics and Statistics 95(2), 660-672.

Bellows, J. and E. Miguel (2009) "War and local collective action in Sierra Leone” Journal of Public Economics 93(11), 1144-1157.

Björklund, A., M. Jäntti, and G. Solon, "Influences of Nature and Nurture on Earnings Variation: A Report on a Study of Sibling Types in Sweden," in Samuel Bowles, Herbert Gintis, and Melissa Osborne, eds., Unequal Chances: Family Background and Economic Success (New York: Russell Sage Foundation, 2005).

Björklund, A., M.Lindahl, and E. Plug (2004) "Intergenerational Effects in Sweden: What Can We Learn from Adoption Data?” IZA, Discussion Paper 1194.

Björklund, A., M. Lindahl, and E. Plug (2006) “The Origins of Intergenerational Associations: Lessons from Swedish adoption data” The Quarterly Journal of Economics, 999-1028.

Black, S. E. and P. J. Devereux (2011) "Recent Developments in the Study of Intergenerational Mobility” in David Card and Orley Ashenfelter (eds.) Handbook of Labor Economics, 4, 1487-1541.

Black, S.E., P. J. Devereux, P. Lundborg, and K. Majlesi (2015) Poor Little Rich Kids? The Determinants of the Intergenerational Transmission of Wealth (No. w21409). National Bureau of Economic Research.

Black, S.E., P. J. Devereux and K. G. Salvanes (2007) "From the Cradle to the Job Market? The Effect of Birth Weight on Adult Outcomes of Children” The Quarterly Journal of Economics 122(1), 409-439.

Bohman, M.(1970) Adopted Children and their Families. Stockholm: Proprius.

Brandén, G., M. Lindahl and B. Öckert (2015) "The importance of nature-nurture interactions for behavioral and economic outcomes: Evidence from a large sample of Swedish adoptees", Mimeo, Uppsala Universitet 
Case, A., A. Fertig and C. Paxson (2003) "From Cradle to Grave? The Lasting Impact of Childhood Health and Circumstance” Working Paper w9788. National Bureau of Economic Research.

Case, A., D. Lubotsky and C. Paxson (2002) "Economic Status and Health in Childhood: The Origins of the Gradient” The American Economic Review 92(5), 1308-1334.

Cesarini, D., M. Johannesson and S. Oskarsson (2014). "Pre-birth Factors, Post-birth Factors, and Voting: Evidence from Swedish Adoption Data” American Political Science Review 108(1), 71-87.

Cesarini, D., E. Lindqvist, R. Östling and B. Wallace (2015) "Wealth, Health, and Child Development: Evidence from Administrative Data on Swedish Lottery Players,” IFN Working Paper 1060.

Chetty, R., S. Abraham, S. Lin, M. Stepner, N. Turner, B. Scuderi and D. Cutler (2015) "Inequality and Mortality: The Geography of Mortality-Income Gradient in the United States" Presentation at the NBER Summer Institute 2015.

Christensen, K. and J.W. Vaupel (1996) “Determinants of Longevity: Genetic, Environmental and Medical Factors” Journal of Internal Medicine 240(6), 333-341.

Classen, T. J. (2010) "Measures of the intergenerational transmission of body mass index between mothers and their children in the United States, 1981-2004” Economics \& Human Biology 8(1), 30-43.

Cohen, B. H. (1964) “Family patterns of mortality and life span” Quarterly Review of Biology, 130-181.

Currie, J. (2000) "Child health in developed countries”, in: A.J. Culyer and J.P. Newhouse (eds.), Handbook of Health Economics (Elsevier, Amsterdam) Chapter 19.

Currie, J. (2011) “Inequality at birth: Some causes and consequences” Working Paper. w16798. National Bureau of Economic Research.

Currie, J., and Goodman, J. (2010) "Parental Socioeconomic Status, Child Health, and Human Capital” in International Encyclopedia of Education 2, 253-259.

Currie, J., and E. Moretti. (2002) "Mother's education and the intergenerational transmission of human capital: evidence from college openings and longitudinal data" Working Paper w9360. National Bureau of Economic Research.

Currie, J. and E. Moretti (2007) "Biology as Destiny? Short- and Long-Run Determinants of Intergenerational Transmission of Birth Weight” Journal of Labor Economics 25, 231-264.

Deaton, A. (2003) “Health, Inequality and Economic Development” Journal of Economic Literature 41, 113-158.

Fagereng, A., M. Mogstad, and M. Rønning, M. (2014) "Influences of Family Environment on Financial Decision Making”. 
Figlio, D., J. Guryan, K. Karbownik and J. Roth (2014) “The Effects of Poor Neonatal Health on Children's Cognitive Development” The American Economic Review 104(12), 3921-55.

Galton, F. (1886) "Regression towards mediocrity in hereditary stature” The Journal of the Anthropological Institute of Great Britain and Ireland 15, 246-263.

Grossman, M. (2000), “The Human Capital Model”, in: A.J. Culyer and J.P. Newhouse, eds., Handbook of Health Economics (Amsterdam: Elsevier) Chapter 7.

Herskind, A. M., M. McGue, N. V. Holm, T. I. A. Sørensen, B. Harvald and J. W. Vaupel (1996) "The heritability of human longevity: a population-based study of 2,872 Danish twin pairs born 1870-1900” Human Genetics, 97, 319-323.

Hjalmarsson, R. and M. J. Lindquist (2013) "The origins of intergenerational associations in crime: lessons from Swedish adoption data” Labour Economics, 20, 68-81.

Hjelmborg, J., Iachine, I., Skytthe, A., Vaupel, J. W., McGue, M., Koskenvuo, M., Kaprio, J., N. Pedersen and Christensen, K. (2006) "Genetic influence on human lifespan and longevity" Human Genetics, 119(3), 312-321.

Holmlund, H., M. Lindahl, and E. Plug (2011) “The causal effect of parents' schooling on children's schooling: A comparison of estimation methods” Journal of Economic Literature 49(3), 615-651.

Johnston, DW, S Schurer, MA Shields (2013) “Exploring the intergenerational persistence of mental health: Evidence from three generations” Journal of Health Economics 32(6), 10771089.

Lindeboom, M., A. Llena-Nozal, and B. van Der Klaauw. (2009) "Parental education and child health: Evidence from a schooling reform.” Journal of Health Economics 28(1), 109131.

Lindquist, M., J. Sol and M. van Praag (2015) "Why Do Entrepreneurial Parents Have Entrepreneurial Children?” Journal of Labor Economics 33(2), 269-296.

Lindquist, M., and R. Hjalmarsson (2013) “The Origins of Intergenerational Associations in Crime: Lessons from Swedish Adoption Data” Labour Economics 20(1), 68-81.

Lundborg, P., A. Nilsson and D. O. Rooth (2014) "Parental education and offspring outcomes: evidence from the Swedish compulsory School Reform” American Economic Journal: Applied Economics 6(1), 253-278.

Marmot, M., M. Shipley, E. Brunner, and H. Hemingway (2001) "Relative contribution of early life and adult socioeconomic factors to adult morbidity in the Whitehall II study" Journal of Epidemiology and Community Health 55(5), 301-307.

Mazumder, B. (2011) "Family and Community Influences on Health and Socioeconomic Status: Sibling Correlations Over the Life Course,” The B.E. Journal of Economic Analysis \& Policy 11(3). 
McCrary, J. and H. Royer (2011) “The Effect of Female Education on Fertility and Infant Health: Evidence from School Entry Policies Using Exact Date of Birth.” The American Economic Review 101(1), 158-195.

Miller, B. C., Fan, X., Grotevant, H. D., Christensen, M., Coyl, D., \& van Dulmen, M. (2000). "Adopted adolescents' overrepresentation in mental health counseling: Adoptees' problems or parents' lower threshold for referral?” Journal of the American Academy of Child \& Adolescent Psychiatry, 39(12), 1504-1511.

Nordlöf, B. (2001) "Svenska adoptioner i Stockholm 1918-1973 (Swedish adoptions in Stockholm 1918-1973)” FOU-rapport 2001:8 Socialtjänstförvaltningen, Stockholm Stad.

Oskarsson, S., K.-O. Lindgren and C. Dawes (2015) “It Runs in the Family”. Mimeo. Department of Political Science, Uppsala University.

Palme, M., and S. Sandgren (2008) "Parental income, lifetime income, and mortality” Journal of the European Economic Association 6(4), 890-911.

Petersen, L., P. Kragh Andersen and T. Sørensen (2005) "Premature Death of Adult Adoptees: Analyses of a Case-Cohort Sample” Genetic Epidemiology 28, 376-382

Petersen, L., P. Kragh Andersen and T. Sørensen (2008) “Genetic and Environmental Effects on Mortality before Age 70 Years” Epidemiology 19(3), 472-476.

Piraino, P., S. Muller, J. Cilliers, and J. Fourie (2014) "The transmission of longevity across generations: The case of the settler Cape Colony” Research in Social Stratification and Mobility 35, 105-119.

Plug, E., and W. Vijverberg (2013) "Schooling, Family Background, and Adoption: Is It Nature or Is It Nurture?” Journal of Political Economy 111, 611-641.

Rietveld C.A., S. Medland, J. Derringer, Authors from the Social Science Genetic Association Consortium, P.M. Visscher, D.J. Benjamin, D. Cesarini and P.D. Koellinger (2013). "GWAS of 126,559 Individuals Identifies Genetic Variants Associated with Educational Attainment” Science 340, 1467-1471.

Sacerdote, B. (2011), "Nature and Nurture Effects On Children’s Outcomes : What Have We Learned From Studies of Twins And Adoptees?” in J. Benhabib, A. Bisin and M. O. Jackson, eds., Handbook of Social Economics (Amsterdam: Elsivier) Chapter 1.

Smith, J. (1999) "Healthy Bodies and Thick Wallets: The Dual Relationship between Health and Economic Status” Journal of Economic Perspectives 13, 145-166.

Solon, G. (1999) “Intergenerational Mobility in the Labor Market” in Orley Ashenfelter and David Card, eds., Handbook of Labor Economics, Volume III (Amsterdam: Elsevier) Chapter 29.

Sørensen, T., G. Nielsen, P. Kragh Andersen and T. Teasdale (1988) "Genetic and Environmental Influences on Premature Death in Adult Adoptees” New England Journal of Medicine 318(12), 727-732. 
Statistics Sweden (2012). Flergenerationsregistret Örebro: Statistics Sweden.

Thompson, O. (2014) "Genetic mechanisms in the intergenerational transmission of health" Journal of Health Economics 35, 132-146.

Wyshak, G. (1978) "Fertility and longevity in twins, sibs, and parents of twins" Social Biology, 25(4), 315-330. 


\section{Appendix}

Figure A1. Share of adoptees of total number of children by year of birth

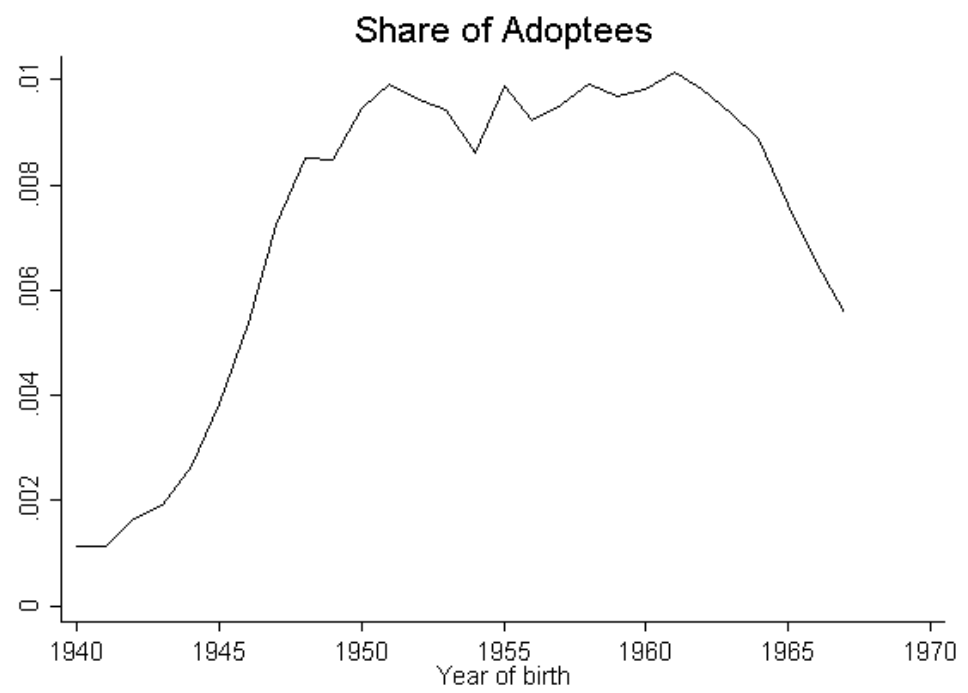

Table A1. Associations between parental life expectancy and child mortality by gender

\begin{tabular}{|c|c|c|c|c|c|c|}
\hline & $\begin{array}{c}(1) \\
\text { Non-adoptees } \\
\text { Men }\end{array}$ & $\begin{array}{c}\text { (2) } \\
\text { Adoptees - Bio } \\
\text { father known } \\
\text { Men }\end{array}$ & $\begin{array}{c}\text { (3) } \\
\text { Adoptees - } \\
\text { Large sample } \\
\text { Men }\end{array}$ & $\begin{array}{c}\text { (4) } \\
\text { Non-adoptees } \\
\text { Women }\end{array}$ & $\begin{array}{c}(5) \\
\text { Adoptees - Bio } \\
\text { father known } \\
\text { Women }\end{array}$ & $\begin{array}{c}(6) \\
\text { Adoptees - } \\
\text { Large sample } \\
\text { Women }\end{array}$ \\
\hline Age at death, Bio Mother & $\begin{array}{l}0.9892^{* * *} \\
(0.0002)\end{array}$ & $\begin{array}{l}0.9878^{* * *} \\
(0.0038)\end{array}$ & $\begin{array}{l}0.9876^{* * *} \\
(0.0026)\end{array}$ & $\begin{array}{c}0.9882^{* * *} \\
(0.0003)\end{array}$ & $\begin{array}{l}0.9833^{* * *} \\
(0.0051)\end{array}$ & $\begin{array}{c}0.9876^{* * *} \\
(0.0035)\end{array}$ \\
\hline Age at death, Bio Father & $\begin{array}{l}0.9905^{* * *} \\
(0.0002)\end{array}$ & $\begin{array}{c}0.9806^{* * *} \\
(0.0039)\end{array}$ & & $\begin{array}{c}0.9924^{* * *} \\
(0.0003)\end{array}$ & $\begin{array}{c}0.9948 \\
(0.0053)\end{array}$ & \\
\hline Age at death, Ad Mother & & $\begin{array}{c}1.0018 \\
(0.0048)\end{array}$ & $\begin{array}{c}0.9986 \\
(0.0029)\end{array}$ & & $\begin{array}{c}0.9905^{*} \\
(0.0056)\end{array}$ & $\begin{array}{c}0.9977 \\
(0.0040)\end{array}$ \\
\hline Age at death, Ad Father & & $\begin{array}{c}1.0020 \\
(0.0045)\end{array}$ & $\begin{array}{c}0.9989 \\
(0.0028)\end{array}$ & & $\begin{array}{c}0.9990 \\
(0.0060)\end{array}$ & $\begin{array}{c}1.0025 \\
(0.0041)\end{array}$ \\
\hline \multicolumn{7}{|l|}{$P$-value joint significance } \\
\hline Biological parents & 0.0000 & 0.0000 & 0.0000 & 0.0000 & 0.0022 & 0.0005 \\
\hline Adoptive parents & & 0.8471 & 0.8198 & & 0.2438 & 0.6990 \\
\hline Observations & $1,447,310$ & 5,619 & 11,071 & $1,380,768$ & 5,218 & 10,135 \\
\hline
\end{tabular}


Table A2. Associations between parental years of schooling and child mortality by gender

\begin{tabular}{|c|c|c|c|c|c|c|}
\hline & $\begin{array}{c}\text { (1) } \\
\text { Non-adoptees } \\
\text { Men }\end{array}$ & $\begin{array}{c}(2) \\
\text { Adoptees - Bio } \\
\text { father known } \\
\text { Men }\end{array}$ & $\begin{array}{c}\text { (3) } \\
\text { Adoptees - } \\
\text { Large sample } \\
\text { Men }\end{array}$ & $\begin{array}{c}\text { (4) } \\
\text { Non-adoptees } \\
\text { Women }\end{array}$ & $\begin{array}{c}5) \\
\text { Adoptees - Bio } \\
\text { father known } \\
\text { Women }\end{array}$ & $\begin{array}{c}(6) \\
\text { Adoptees - } \\
\text { Large sample } \\
\text { Women }\end{array}$ \\
\hline Years of education, Bio Mother & $\begin{array}{l}0.9738^{* * *} \\
(0.0019)\end{array}$ & $\begin{array}{c}1.0269 \\
(0.0311)\end{array}$ & $\begin{array}{c}0.9760 \\
(0.0192)\end{array}$ & $\begin{array}{l}0.9820^{* * *} \\
(0.0024)\end{array}$ & $\begin{array}{l}1.0771^{* *} \\
(0.0386)\end{array}$ & $\begin{array}{c}1.0140 \\
(0.0238)\end{array}$ \\
\hline Years of education, Bio Father & $\begin{array}{c}0.9690^{* * *} \\
(0.0013)\end{array}$ & $\begin{array}{c}0.9819 \\
(0.0224)\end{array}$ & & $\begin{array}{c}0.9839^{* * *} \\
(0.0017)\end{array}$ & $\begin{array}{c}1.0001 \\
(0.0295)\end{array}$ & \\
\hline Years of education, Ad Mother & & $\begin{array}{c}0.9602 \\
(0.0278)\end{array}$ & $\begin{array}{c}0.9759 \\
(0.0179)\end{array}$ & & $\begin{array}{c}0.9441^{*} \\
(0.0316)\end{array}$ & $\begin{array}{c}0.9630^{*} \\
(0.0215)\end{array}$ \\
\hline Years of education, Ad Father & & $\begin{array}{c}0.9791 \\
(0.0206)\end{array}$ & $\begin{array}{c}0.9983 \\
(0.0132)\end{array}$ & & $\begin{array}{c}1.0126 \\
(0.0244)\end{array}$ & $\begin{array}{c}0.9985 \\
(0.0162)\end{array}$ \\
\hline \multicolumn{7}{|l|}{$P$-value joint significance } \\
\hline $\begin{array}{l}\text { Biological parents } \\
\text { Adoptive parents }\end{array}$ & 0.0000 & $\begin{array}{l}0.5358 \\
0.0420\end{array}$ & $\begin{array}{l}0.2177 \\
0.2707\end{array}$ & 0.0000 & $\begin{array}{l}0.0901 \\
0.2161\end{array}$ & $\begin{array}{l}0.5548 \\
0.1633\end{array}$ \\
\hline Observations & 144,7310 & 5,619 & 11,071 & $1,380,768$ & 5,218 & 10,135 \\
\hline $\begin{array}{l}\text { Note: Results from Cox } \\
5 \%, * \text { at } 10 \% \text {. Each col } \\
\text { cohort of children, and } \\
\text { consists of women. Colur } \\
\text { adoptees for whom we }\end{array}$ & $\begin{array}{l}\text { portional ha } \\
\text { in represent } \\
\text { e-year interv } \\
\text { s (1) and (4) } \\
\text { je informati }\end{array}$ & $\begin{array}{l}\text { ird models. } S \\
\text { a separate } r \\
\text { ls for paren } \\
\text { are based on }\end{array}$ & $\begin{array}{l}\text { dard errors } \\
\text { ession and } \\
\text { cohorts. C } \\
\text { ample of } n \\
\text {, and in }\end{array}$ & $\begin{array}{l}\text { parentheses } \\
\text { regression } \\
\text { nns (1)-(3) } \\
\text { adopted chi } \\
\text { mns (3) an }\end{array}$ & $\begin{array}{l}* * \text { significa } \\
\text { aclude indic } \\
\text { onsists of m } \\
\text { en, columns } \\
\text { (6) we add }\end{array}$ & $\begin{array}{l}\text { at } 1 \%, * * \text { at } \\
\text { rs for birth } \\
\text { and (4)-(6) } \\
\text { ) and (5) on } \\
\text { optees with }\end{array}$ \\
\hline
\end{tabular}


Table A3. Associations between parental life expectancy, years of schooling and child health, measured as Hospitalization

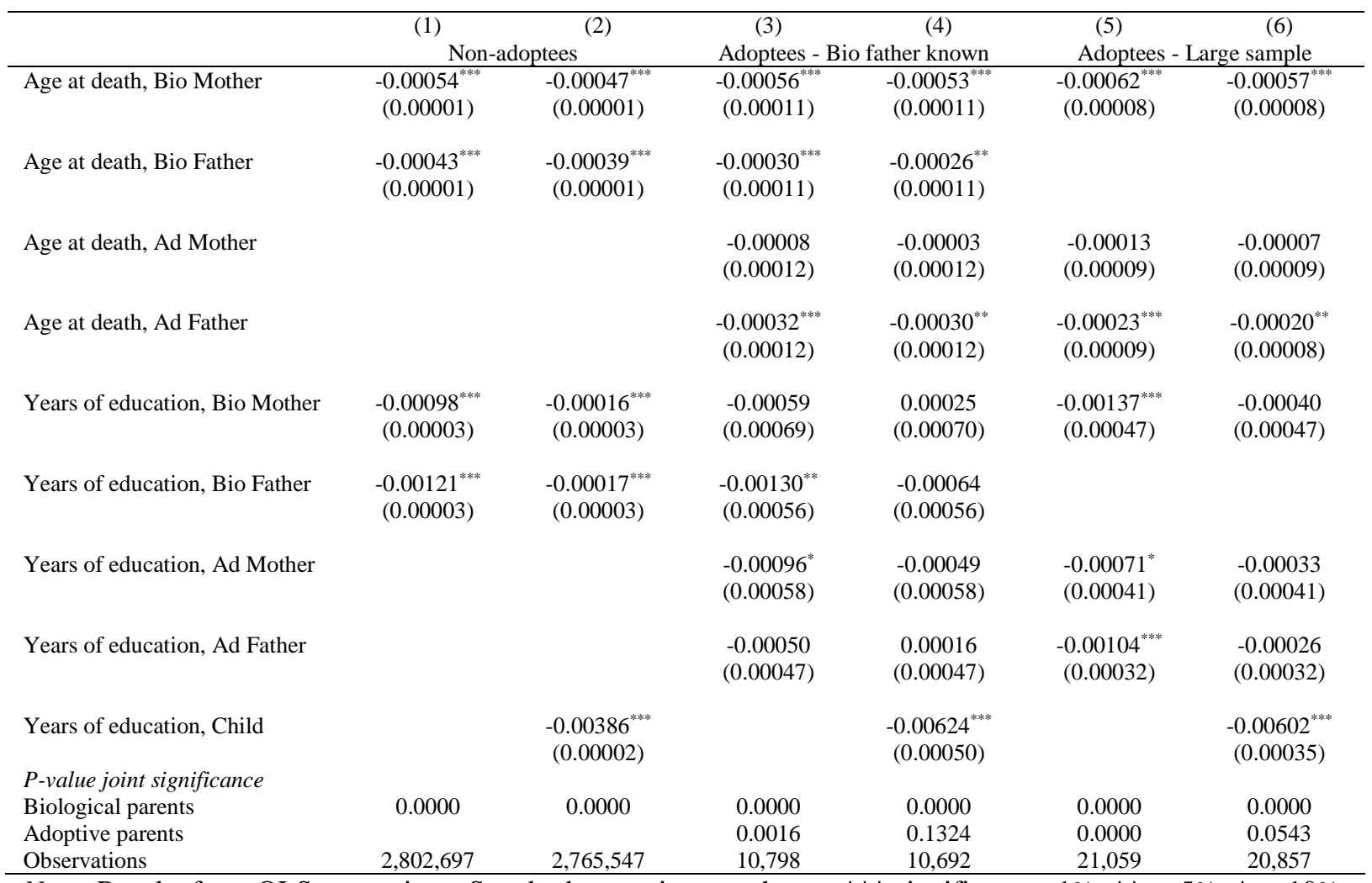

Note: Results from OLS regressions. Standard errors in parentheses; *** significant at 1\%, ** at 5\%, * at $10 \%$. Each column represents a separate regression and all regressions include indicators for gender and birth cohort of children, and five-year intervals for parental cohorts. Columns (1)-(2) are based on a sample of non-adopted children, columns (3)-(4) on adoptees for whom we have information on all parents, and in columns (5)-(6) we add adoptees with unknown biological fathers. Adding children's years of schooling in column (2), (4) and (6) reduces the number of observations slightly because we do not have educational attainment for all children. 
Table A4. Associations between parental life expectancy, years of schooling and child health, measured as Health index

\begin{tabular}{|c|c|c|c|c|c|c|}
\hline \multirow{3}{*}{ Age at death, Bio Mother } & \multirow{2}{*}{\multicolumn{2}{|c|}{ (1) }} & \multirow{2}{*}{\multicolumn{2}{|c|}{$\begin{array}{c}\text { (3) } \\
\text { Adoptees - Bio father known }\end{array}$}} & \multirow{2}{*}{\multicolumn{2}{|c|}{$\begin{array}{l}\text { (5) } \\
\text { Adoptees - Large sample }\end{array}$}} \\
\hline & & & & & & \\
\hline & $\begin{array}{l}-0.00005^{* * *} \\
(0.00000)\end{array}$ & $\begin{array}{c}-0.00005^{* * *} \\
(0.00000)\end{array}$ & $\begin{array}{c}-0.00007^{* * * *} \\
(0.00002)\end{array}$ & $\begin{array}{c}-0.00007^{* * *} \\
(0.00001)\end{array}$ & $\begin{array}{l}-0.00006^{* * * *} \\
(0.00001)\end{array}$ & $\begin{array}{c}-0.00006^{* * * *} \\
(0.00001)\end{array}$ \\
\hline Age at death, Bio Father & $\begin{array}{c}-0.00004^{* * *} \\
(0.00000)\end{array}$ & $\begin{array}{c}-0.00003^{* * *} \\
(0.00000)\end{array}$ & $\begin{array}{l}-0.00004^{* *} \\
(0.00002)\end{array}$ & $\begin{array}{l}-0.00003^{*} \\
(0.00001)\end{array}$ & & \\
\hline Age at death, Ad Mother & & & $\begin{array}{c}0.00000 \\
(0.00002)\end{array}$ & $\begin{array}{c}0.00000 \\
(0.00002)\end{array}$ & $\begin{array}{l}-0.00000 \\
(0.00001)\end{array}$ & $\begin{array}{c}0.00000 \\
(0.00001)\end{array}$ \\
\hline Age at death, Ad Father & & & $\begin{array}{l}-0.00002 \\
(0.00002)\end{array}$ & $\begin{array}{l}-0.00002 \\
(0.00002)\end{array}$ & $\begin{array}{l}-0.00002^{*} \\
(0.00001)\end{array}$ & $\begin{array}{l}-0.00002^{*} \\
(0.00001)\end{array}$ \\
\hline Years of education, Bio Mother & $\begin{array}{l}-0.00004^{* * *} \\
(0.00000)\end{array}$ & $\begin{array}{l}0.00003^{* * *} \\
(0.00000)\end{array}$ & $\begin{array}{c}0.00011 \\
(0.00010)\end{array}$ & $\begin{array}{l}0.00021^{* *} \\
(0.00010)\end{array}$ & $\begin{array}{l}-0.00004 \\
(0.00006)\end{array}$ & $\begin{array}{c}0.00007 \\
(0.00006)\end{array}$ \\
\hline Years of education, Bio Father & $\begin{array}{c}-0.00007^{* * *} \\
(0.00000)\end{array}$ & $\begin{array}{l}0.00003^{* * *} \\
(0.00000)\end{array}$ & $\begin{array}{l}-0.00007 \\
(0.00008)\end{array}$ & $\begin{array}{c}0.00000 \\
(0.00008)\end{array}$ & & \\
\hline Years of education, Ad Mother & & & $\begin{array}{l}-0.00010 \\
(0.00007)\end{array}$ & $\begin{array}{l}-0.00003 \\
(0.00007)\end{array}$ & $\begin{array}{l}-0.00006 \\
(0.00006)\end{array}$ & $\begin{array}{l}-0.00002 \\
(0.00005)\end{array}$ \\
\hline Years of education, Ad Father & & & $\begin{array}{c}0.00002 \\
(0.00006)\end{array}$ & $\begin{array}{c}0.00007 \\
(0.00006)\end{array}$ & $\begin{array}{c}0.00000 \\
(0.00004)\end{array}$ & $\begin{array}{c}0.00007^{*} \\
(0.00004)\end{array}$ \\
\hline Years of education, Child & & $\begin{array}{c}-0.00035^{* * *} \\
(0.00000)\end{array}$ & & $\begin{array}{c}-0.00063^{* * *} \\
(0.00007)\end{array}$ & & $\begin{array}{c}-0.00057^{* * *} \\
(0.00005)\end{array}$ \\
\hline$P$-value joint significance & & & & & & \\
\hline Biological parents & 0.0000 & 0.0000 & 0.0000 & 0.0001 & 0.0000 & 0.0000 \\
\hline Adoptive parents & & & 0.2684 & 0.4305 & 0.3641 & 0.2013 \\
\hline Observations & 2802697 & 2765547 & 10798 & 10692 & 21059 & 20857 \\
\hline
\end{tabular}

Note: Results from OLS regressions. Standard errors in parentheses; *** significant at 1\%, ** at 5\%, * at $10 \%$.

Each column represents a separate regression and all regressions include indicators for gender and birth cohort of children, and five-year intervals for parental cohorts. Columns (1)-(2) are based on a sample of non-adopted children, columns (3)-(4) on adoptees for whom we have information on all parents, and in columns (5)-(6) we add adoptees with unknown biological fathers. Adding children's years of schooling in column (2), (4) and (6) reduces the number of observations slightly because we do not have educational attainment for all children. 
Table A5. Associations between parental life expectancy, years of schooling and child mortality by cohort

\begin{tabular}{|c|c|c|c|c|c|c|}
\hline & $\begin{array}{l}(1) \\
<55\end{array}$ & $\begin{array}{l}(2) \\
<55\end{array}$ & $\begin{array}{c}(3) \\
>=55\end{array}$ & $\begin{array}{c}(4) \\
>=55\end{array}$ & $\begin{array}{l}\text { (5) } \\
\text { All }\end{array}$ & $\begin{array}{l}\text { (6) } \\
\text { All }\end{array}$ \\
\hline Age at death, Bio Mother & $\begin{array}{c}0.9843^{* * *} \\
(0.0029)\end{array}$ & & $\begin{array}{c}0.9853^{* * *} \\
(0.0032)\end{array}$ & & $\begin{array}{c}0.9849^{* * *} \\
(0.0021)\end{array}$ & \\
\hline Age at death, Ad Mother & $\begin{array}{c}0.9967 \\
(0.0031)\end{array}$ & & $\begin{array}{c}0.9960 \\
(0.0040)\end{array}$ & & $\begin{array}{c}0.9964 \\
(0.0024)\end{array}$ & \\
\hline Age at death, Ad Father & $\begin{array}{c}0.9979 \\
(0.0031)\end{array}$ & & $\begin{array}{c}0.9987 \\
(0.0041)\end{array}$ & & $\begin{array}{c}0.9981 \\
(0.0025)\end{array}$ & \\
\hline Years of education, Bio Mother & & $\begin{array}{c}0.9880 \\
(0.0202)\end{array}$ & & $\begin{array}{c}0.9934 \\
(0.0252)\end{array}$ & & $\begin{array}{c}0.9889 \\
(0.0157)\end{array}$ \\
\hline Years of education, Ad Mother & & $\begin{array}{c}0.9768 \\
(0.0209)\end{array}$ & & $\begin{array}{c}0.9605^{*} \\
(0.0216)\end{array}$ & & $\begin{array}{l}0.9684^{* *} \\
(0.0148)\end{array}$ \\
\hline Years of education, Ad Father & & $\begin{array}{c}0.9933 \\
(0.0139)\end{array}$ & & $\begin{array}{c}0.9925 \\
(0.0178)\end{array}$ & & $\begin{array}{c}0.9942 \\
(0.0110)\end{array}$ \\
\hline p-value joint significance & & & & & & \\
\hline Biological parents & 0.0000 & 0.5545 & 0.0000 & 0.7934 & 0.0000 & 0.4816 \\
\hline Adoptive parents & 0.4583 & 0.3070 & 0.5506 & 0.0454 & 0.2487 & 0.0229 \\
\hline Observations & 9,009 & 9,009 & 12,050 & 12,050 & 21,059 & 21,059 \\
\hline
\end{tabular}

Note: Results from Cox proportional hazard models using the large sample of adoptees used for hospitalization estimation, i.e. still alive in 1987, to be comparable with A6 and A7. Standard errors in parentheses; *** significant at $1 \%, * *$ at $5 \%, *$ at $10 \%$. Each column represents a separate regression and all regressions include indicators for birth cohort of children, and five-year intervals for parental cohorts. Columns (1)-(2) consists adoptees born before January $1^{\text {st }} 1955$, and (3)-(4) consists of adoptees born January $1^{\text {st }} 1955$ or later. Columns (5)-(6) consists of the sum of these samples. 
Table A6. Associations between parental life expectancy, years of schooling and child health (Hospitalization) by cohort

\begin{tabular}{|c|c|c|c|c|c|c|}
\hline & $\begin{array}{l}(1) \\
<55 \\
\end{array}$ & $\begin{array}{l}(2) \\
<55\end{array}$ & $\begin{array}{c}(3) \\
>=55\end{array}$ & $\begin{array}{c}(4) \\
>=55\end{array}$ & $\begin{array}{l}\text { (5) } \\
\text { All }\end{array}$ & $\begin{array}{l}\text { (6) } \\
\text { All }\end{array}$ \\
\hline Age at death, Bio Mother & $\begin{array}{c}-0.0008^{* * *} \\
(0.0001)\end{array}$ & & $\begin{array}{c}-0.0006^{* * *} \\
(0.0001)\end{array}$ & & $\begin{array}{c}-0.0007^{* * *} \\
(0.0001)\end{array}$ & \\
\hline Age at death, Ad Mother & $\begin{array}{c}-0.0001 \\
(0.0001)\end{array}$ & & $\begin{array}{l}-0.0002^{*} \\
(0.0001)\end{array}$ & & $\begin{array}{l}-0.0002^{*} \\
(0.0001)\end{array}$ & \\
\hline Age at death, Ad Father & $\begin{array}{c}-0.0002 \\
(0.0001)\end{array}$ & & $\begin{array}{c}-0.0003^{* * *} \\
(0.0001)\end{array}$ & & $\begin{array}{c}-0.0003^{* * *} \\
(0.0001)\end{array}$ & \\
\hline Years of education, Bio Mother & & $\begin{array}{c}-0.0008 \\
(0.0009)\end{array}$ & & $\begin{array}{c}-0.0023^{* * *} \\
(0.0005)\end{array}$ & & $\begin{array}{c}-0.0018^{* * *} \\
(0.0005)\end{array}$ \\
\hline Years of education, Ad Mother & & $\begin{array}{l}-0.0006 \\
(0.0008)\end{array}$ & & $\begin{array}{l}-0.0009^{*} \\
(0.0005)\end{array}$ & & $\begin{array}{c}-0.0008^{* *} \\
(0.0004)\end{array}$ \\
\hline Years of education, Ad Father & & $\begin{array}{c}-0.0015^{* * *} \\
(0.0005)\end{array}$ & & $\begin{array}{c}-0.0011^{* * *} \\
(0.0004)\end{array}$ & & $\begin{array}{c}-0.0012^{* * *} \\
(0.0003)\end{array}$ \\
\hline $\begin{array}{l}\text { p-value joint significance } \\
\text { Biological parents } \\
\text { Adoptive parents } \\
\text { Observations }\end{array}$ & $\begin{array}{c}0.0000 \\
0.3103 \\
9,009\end{array}$ & $\begin{array}{c}0.3348 \\
0.0031 \\
9,009 \\
\end{array}$ & $\begin{array}{l}0.0000 \\
0.0038 \\
12,050\end{array}$ & $\begin{array}{l}0.0000 \\
0.0000 \\
12,050\end{array}$ & $\begin{array}{l}0.0000 \\
0.0021 \\
21,059\end{array}$ & $\begin{array}{l}0.0002 \\
0.0000 \\
21,059\end{array}$ \\
\hline $\begin{array}{l}\text { Note: Results from OLS regressi } \\
\text { still alive in } 1987 \text {, to be compara } \\
5 \% \text {, * at } 10 \% \text {. Each column repr } \\
\text { cohort of children, and five-year } \\
\text { January } 1^{\text {st }} 1955 \text {, and (3)-(4) con } \\
\text { sum of these samples. }\end{array}$ & $\begin{array}{l}\text { ns using the } \\
\text { le with A6 } \\
\text { sents a sepa } \\
\text { ntervals for } \\
\text { ists of adopt }\end{array}$ & $\begin{array}{l}\text { large sampl } \\
\text { nd A7. Stan } \\
\text { ate regressic } \\
\text { parental coh } \\
\text { ees born Jan }\end{array}$ & $\begin{array}{l}\text { of adoptee } \\
\text { lard errors i } \\
\text { and all re } \\
\text { rts. Colum } \\
\text { ary } 1^{\text {st }} 195\end{array}$ & $\begin{array}{l}\text { used for ho } \\
\text { parenthese } \\
\text { essions inc } \\
(1)-(2) \text { co } \\
\text { or later. Co }\end{array}$ & $\begin{array}{l}\text { talization } \\
k * * \text { signif } \\
\text { le indicato } \\
\text { sts adopte } \\
\text { mns (5)-(6 }\end{array}$ & $\begin{array}{l}\text { stimation, i.e. } \\
\text { ant at } 1 \%, * * \text { a } \\
\text { for birth } \\
\text { born before } \\
\text { consists of the }\end{array}$ \\
\hline
\end{tabular}


Table A7. Associations between parental life expectancy, years of schooling and child health (Health index) by cohort

\begin{tabular}{|c|c|c|c|c|c|c|}
\hline & $\begin{array}{l}(1) \\
<55\end{array}$ & $\begin{array}{l}(2) \\
<55\end{array}$ & $\begin{array}{c}(3) \\
>=55\end{array}$ & $\begin{array}{c}(4) \\
>=55\end{array}$ & $\begin{array}{l}\text { (5) } \\
\text { All }\end{array}$ & $\begin{array}{l}\text { (6) } \\
\text { All }\end{array}$ \\
\hline Age at death, Bio Mother & $\begin{array}{c}-0.0001^{* * *} \\
(0.0000)\end{array}$ & & $\begin{array}{c}-0.0000^{* * *} \\
(0.0000)\end{array}$ & & $\begin{array}{c}-0.0001^{* * *} \\
(0.0000)\end{array}$ & \\
\hline Age at death, Ad Mother & $\begin{array}{l}-0.0000 \\
(0.0000)\end{array}$ & & $\begin{array}{c}0.0000 \\
(0.0000)\end{array}$ & & $\begin{array}{l}-0.0000 \\
(0.0000)\end{array}$ & \\
\hline Age at death, Ad Father & $\begin{array}{l}-0.0000 \\
(0.0000)\end{array}$ & & $\begin{array}{l}-0.0000 \\
(0.0000)\end{array}$ & & $\begin{array}{l}-0.0000^{*} \\
(0.0000)\end{array}$ & \\
\hline Years of education, Bio Mother & & $\begin{array}{c}0.0000 \\
(0.0001)\end{array}$ & & $\begin{array}{c}-0.0001^{* *} \\
(0.0001)\end{array}$ & & $\begin{array}{c}-0.0001 \\
(0.0001)\end{array}$ \\
\hline Years of education, Ad Mother & & $\begin{array}{c}-0.0001 \\
(0.0001)\end{array}$ & & $\begin{array}{c}-0.0001 \\
(0.0001)\end{array}$ & & $\begin{array}{c}-0.0001 \\
(0.0001)\end{array}$ \\
\hline Years of education, Ad Father & & $\begin{array}{c}-0.0001 \\
(0.0001)\end{array}$ & & $\begin{array}{c}0.0000 \\
(0.0000)\end{array}$ & & $\begin{array}{c}-0.0000 \\
(0.0000)\end{array}$ \\
\hline \multicolumn{7}{|l|}{ p-value joint significance } \\
\hline Biological parents & 0.0000 & 0.8102 & 0.0000 & 0.0158 & 0.0000 & 0.1826 \\
\hline Adoptive parents & 0.5529 & 0.1380 & 0.3311 & 0.5970 & 0.1856 & 0.2369 \\
\hline Observations & 9,009 & 9,009 & 12,050 & 12,050 & 21,059 & 21,059 \\
\hline $\begin{array}{l}\text { Note: Results from OLS regress } \\
\text { still alive in } 1987 \text {, to be compara } \\
5 \% \text {, * at } 10 \% \text {. Each column repr } \\
\text { cohort of children, and five-year } \\
\text { January } 1^{\text {st }} 1955 \text {, and (3)-(4) con } \\
\text { sum of these samples. }\end{array}$ & $\begin{array}{l}\text { ons using th } \\
\text { ole with A6 } \\
\text { sents a sepa } \\
\text { intervals for } \\
\text { ists of adop }\end{array}$ & $\begin{array}{l}\text { large sam } \\
\text { and A7. Sta } \\
\text { ate regress } \\
\text { parental co } \\
\text { ees born } \mathrm{J} \text { c }\end{array}$ & $\begin{array}{l}\text { of adopt } \\
\text { dard error } \\
n \text { and all } \\
\text { jrts. Colu } \\
\text { lary } 1^{\text {st }} 1\end{array}$ & $\begin{array}{l}\text { used for } \\
\text { parenthe } \\
\text { ressions i } \\
\text { (1)-(2) } \\
\text { or later. }\end{array}$ & $\begin{array}{l}\text { spitalizati } \\
\text { s; *** sig } \\
\text { lude indic } \\
\text { nsists adop } \\
\text { lumns (5) }\end{array}$ & $\begin{array}{l}\text { estimation, i.e. } \\
\text { icant at } 1 \% \text {, ** at } \\
\text { ors for birth } \\
\text { es born before } \\
\text { ) consists of the }\end{array}$ \\
\hline
\end{tabular}


Table A8. Associations between parental life expectancy, years of schooling and the prevalence of low birth weight $(<2,500$ gram) among firstborn grandchild

\begin{tabular}{|c|c|c|c|c|c|c|}
\hline \multirow{3}{*}{ Age at death, Bio Mother } & (1) & (2) & (3) & (4) & (5) & (6) \\
\hline & \multicolumn{2}{|c|}{ Non-adoptees } & \multicolumn{2}{|c|}{ Adoptees - Bio father known } & \multicolumn{2}{|c|}{ Adoptees - Large sample } \\
\hline & $\begin{array}{c}-0.00017^{* * *} \\
(0.00002)\end{array}$ & $\begin{array}{c}-0.00014^{* * *} \\
(0.00002)\end{array}$ & $\begin{array}{l}-0.00051 \\
(0.00036)\end{array}$ & $\begin{array}{l}-0.00052 \\
(0.00036)\end{array}$ & $\begin{array}{l}-0.00029 \\
(0.00026)\end{array}$ & $\begin{array}{l}-0.00026 \\
(0.00026)\end{array}$ \\
\hline Age at death, Bio Father & $\begin{array}{c}-0.00023^{* * *} \\
(0.00002)\end{array}$ & $\begin{array}{c}-0.00021^{* * *} \\
(0.00002)\end{array}$ & $\begin{array}{l}-0.00039 \\
(0.00039)\end{array}$ & $\begin{array}{l}-0.00040 \\
(0.00039)\end{array}$ & & \\
\hline Age at death, Ad Mother & & & $\begin{array}{l}-0.00002 \\
(0.00042)\end{array}$ & $\begin{array}{l}-0.00002 \\
(0.00042)\end{array}$ & $\begin{array}{l}-0.00004 \\
(0.00030)\end{array}$ & $\begin{array}{l}-0.00000 \\
(0.00030)\end{array}$ \\
\hline Age at death, Ad Father & & & $\begin{array}{c}0.00073^{*} \\
(0.00038)\end{array}$ & $\begin{array}{c}0.00073^{*} \\
(0.00038)\end{array}$ & $\begin{array}{c}0.00055^{*} \\
(0.00029)\end{array}$ & $\begin{array}{l}0.00057^{* *} \\
(0.00029)\end{array}$ \\
\hline Years of education, Bio Mother & $\begin{array}{c}-0.00063^{* * *} \\
(0.00013)\end{array}$ & $\begin{array}{c}-0.00016 \\
(0.00013)\end{array}$ & $\begin{array}{c}0.00290 \\
(0.00242)\end{array}$ & $\begin{array}{c}0.00282 \\
(0.00245)\end{array}$ & $\begin{array}{c}0.00218 \\
(0.00171)\end{array}$ & $\begin{array}{c}0.00267 \\
(0.00173)\end{array}$ \\
\hline Years of education, Bio Father & $\begin{array}{c}-0.00071^{* * *} \\
(0.00010)\end{array}$ & $\begin{array}{c}-0.00030^{* * *} \\
(0.00010)\end{array}$ & $\begin{array}{l}-0.00087 \\
(0.00212)\end{array}$ & $\begin{array}{l}-0.00092 \\
(0.00212)\end{array}$ & & \\
\hline Years of education, Ad Mother & & & $\begin{array}{l}-0.00064 \\
(0.00201)\end{array}$ & $\begin{array}{l}-0.00069 \\
(0.00201)\end{array}$ & $\begin{array}{l}-0.00050 \\
(0.00139)\end{array}$ & $\begin{array}{l}-0.00024 \\
(0.00139)\end{array}$ \\
\hline Years of education, Ad Father & & & $\begin{array}{l}-0.00165 \\
(0.00159)\end{array}$ & $\begin{array}{l}-0.00168 \\
(0.00159)\end{array}$ & $\begin{array}{l}-0.00208^{*} \\
(0.00111)\end{array}$ & $\begin{array}{l}-0.00181 \\
(0.00111)\end{array}$ \\
\hline Years of education, Child & & $\begin{array}{c}-0.00217^{* * *} \\
(0.00011)\end{array}$ & & $\begin{array}{c}0.00063 \\
(0.00201)\end{array}$ & & $\begin{array}{c}-0.00323^{* *} \\
(0.00135)\end{array}$ \\
\hline$P$-value joint significance & & & & & & \\
\hline Biological parents & 0.0000 & 0.0000 & 0.3551 & 0.3560 & 0.2500 & 0.1918 \\
\hline Adoptive parents & & & 0.2680 & 0.2625 & 0.0675 & 0.1244 \\
\hline Observations & 790,128 & 788,707 & 3,469 & 3,465 & 6,399 & 6,389 \\
\hline
\end{tabular}

Note: Results from OLS regressions. Standard errors in parentheses; $* * *$ significant at $1 \%, * *$ at $5 \%$, * at $10 \%$. Each column represents a separate regression and all regressions include indicators for gender and birth cohort of children, and five-year intervals for parental cohorts. Columns (1)-(2) are based on a sample of non-adopted children, columns (3)-(4) on adoptees for whom we have information on all parents, and in columns (5)-(6) we add adoptees with unknown biological fathers. Adding children's years of schooling in column (2), (4) and (6) reduces the number of observations slightly because we do not have educational attainment for all children. 
Table A9. Associations between parental life expectancy, years of schooling and birth weight of firstborn grandchild

\begin{tabular}{|c|c|c|c|c|c|c|}
\hline & \multirow{2}{*}{\multicolumn{2}{|c|}{$\begin{array}{l}\text { (1) } \\
\text { Non-adoptees }\end{array}$}} & \multirow{2}{*}{\multicolumn{2}{|c|}{$\begin{array}{c}\text { (3) } \\
\text { Adoptees - Bio father known }\end{array}$}} & \multirow{2}{*}{\multicolumn{2}{|c|}{$\begin{array}{cc}(5) & (6) \\
\text { Adoptees - Large sample }\end{array}$}} \\
\hline & & & & & & \\
\hline Age at death, Bio Mother & $\begin{array}{l}0.56495^{* * *} \\
(0.06252)\end{array}$ & $\begin{array}{l}0.41975^{* * *} \\
(0.06260)\end{array}$ & $\begin{array}{l}1.55194^{*} \\
(0.84307)\end{array}$ & $\begin{array}{l}1.54736^{*} \\
(0.84447)\end{array}$ & $\begin{array}{l}1.23068^{*} \\
(0.63039)\end{array}$ & $\begin{array}{l}1.14503^{*} \\
(0.63086)\end{array}$ \\
\hline Age at death, Bio Father & $\begin{array}{l}1.08489^{* * *} \\
(0.05722)\end{array}$ & $\begin{array}{l}0.97716^{* * *} \\
(0.05727)\end{array}$ & $\begin{array}{l}-0.42591 \\
(0.89663)\end{array}$ & $\begin{array}{l}-0.43073 \\
(0.89940)\end{array}$ & & \\
\hline Age at death, Ad Mother & & & $\begin{array}{c}0.45051 \\
(1.00735)\end{array}$ & $\begin{array}{c}0.43909 \\
(1.00818)\end{array}$ & $\begin{array}{c}0.87962 \\
(0.74299)\end{array}$ & $\begin{array}{c}0.78823 \\
(0.74397)\end{array}$ \\
\hline Age at death, Ad Father & & & $\begin{array}{l}-1.82323^{*} \\
(0.95384)\end{array}$ & $\begin{array}{l}-1.84813^{*} \\
(0.95340)\end{array}$ & $\begin{array}{l}-1.00814 \\
(0.70227)\end{array}$ & $\begin{array}{l}-1.08077 \\
(0.70130)\end{array}$ \\
\hline Years of education, Bio Mother & $\begin{array}{l}3.88163^{* * *} \\
(0.33536)\end{array}$ & $\begin{array}{l}1.63951^{* * *} \\
(0.33985)\end{array}$ & $\begin{array}{c}6.65730 \\
(6.16373)\end{array}$ & $\begin{array}{c}6.08059 \\
(6.20601)\end{array}$ & $\begin{array}{c}4.09469 \\
(4.15132)\end{array}$ & $\begin{array}{c}2.49973 \\
(4.19616)\end{array}$ \\
\hline Years of education, Bio Father & $\begin{array}{l}2.34316^{* * *} \\
(0.26660)\end{array}$ & $\begin{array}{c}0.33606 \\
(0.27131)\end{array}$ & $\begin{array}{l}-5.09660 \\
(5.17107)\end{array}$ & $\begin{array}{l}-5.17389 \\
(5.19061)\end{array}$ & & \\
\hline Years of education, Ad Mother & & & $\begin{array}{c}0.70929 \\
(4.94836)\end{array}$ & $\begin{array}{c}0.69453 \\
(4.96041)\end{array}$ & $\begin{array}{c}-4.27631 \\
(3.49682)\end{array}$ & $\begin{array}{l}-4.86823 \\
(3.50489)\end{array}$ \\
\hline Years of education, Ad Father & & & $\begin{array}{c}5.06643 \\
(3.94763)\end{array}$ & $\begin{array}{c}4.91405 \\
(3.96401)\end{array}$ & $\begin{array}{l}6.20527^{* *} \\
(2.80706)\end{array}$ & $\begin{array}{c}5.29512^{*} \\
(2.81677)\end{array}$ \\
\hline Years of education, Child & & $\begin{array}{c}10.62078^{* * *} \\
(0.27158)\end{array}$ & & $\begin{array}{c}2.38947 \\
(4.56983)\end{array}$ & & $\begin{array}{c}10.82409^{* * *} \\
(3.18883)\end{array}$ \\
\hline$P$-value joint significance & & & & & & \\
\hline Biological parents & 0.0000 & 0.0000 & 0.2033 & 0.2192 & 0.0797 & 0.1495 \\
\hline Adoptive parents & & & 0.2098 & 0.2169 & 0.0909 & 0.1375 \\
\hline Observations & 790,128 & 788,707 & 3,469 & 3,465 & 6,399 & 6,389 \\
\hline
\end{tabular}

Note: Results from OLS regressions. Standard errors in parentheses; *** significant at 1\%, ** at 5\%, * at $10 \%$. Each column represents a separate regression and all regressions include indicators for gender and birth cohort of children, and five-year intervals for parental cohorts. Columns (1)-(2) are based on a sample of non-adopted children, columns (3)-(4) on adoptees for whom we have information on all parents, and in columns (5)-(6) we add adoptees with unknown biological fathers. Adding children's years of schooling in column (2), (4) and (6) reduces the number of observations slightly because we do not have educational attainment for all children. 
Table A10. Associations between parental life expectancy, years of schooling and child mortality

\begin{tabular}{|c|c|c|c|c|}
\hline & $(1)$ & $(2)$ & (3) & $(4)$ \\
\hline Age at death, Bio Mother & $\begin{array}{c}-0.000872^{* * *} \\
(0.000160)\end{array}$ & $\begin{array}{c}-0.000858^{* * *} \\
(0.000161)\end{array}$ & & $\begin{array}{c}-0.000974^{* * * *} \\
(0.000271)\end{array}$ \\
\hline Years of education, Ad Mother & & $\begin{array}{c}-0.001596 * * \\
(0.000790)\end{array}$ & $\begin{array}{c}-0.001830^{* * *} \\
(0.000653)\end{array}$ & $\begin{array}{c}-0.002102^{* * *} \\
(0.000669)\end{array}$ \\
\hline Years of education, Ad Father & & $\begin{array}{c}-0.000297 \\
(0.000676)\end{array}$ & & \\
\hline Age at death, Ad Mother & & $\begin{array}{c}-0.000255 \\
(0.000250)\end{array}$ & & \\
\hline Age at death, Ad Father & & $\begin{array}{l}-0.000018 \\
(0.000212)\end{array}$ & & \\
\hline Years of education, Bio Mother & & & & $\begin{array}{l}-0.000387 \\
(0.000958)\end{array}$ \\
\hline Cohorts, Bio mother & Yes & Yes & No & Yes \\
\hline Cohorts, Ad mother & No & Yes & Yes & Yes \\
\hline Cohort, Ad father & No & Yes & No & No \\
\hline Cause of death, Bio mother & No & No & No & Yes \\
\hline Region, Bio mother & No & No & No & Yes \\
\hline Cause of death, Ad mother & No & Yes & No & No \\
\hline Cause of death, Ad father & No & Yes & No & No \\
\hline Region, Ad parents & No & Yes & No & No \\
\hline Observations & 21,206 & 21,206 & 21,206 & 21,206 \\
\hline
\end{tabular}

Note: Results from a linear probability model using the large sample of adoptees. Standard errors in parentheses; $* * *$ significant at $1 \%, * *$ at $5 \%, *$ at $10 \%$. Each column represents a separate regression and all regressions include indicators for gender and birth cohort of children. Each column is adding parental characteristics. 
Table A11. Interaction effects

\begin{tabular}{|c|c|c|c|c|c|c|}
\hline & \multirow{2}{*}{\multicolumn{2}{|c|}{ (1) Mortal }} & \multirow{2}{*}{\multicolumn{2}{|c|}{$\begin{array}{l}\text { (3) (4) } \\
\text { Hospitalization }\end{array}$}} & \multicolumn{2}{|c|}{ (5) (6) } \\
\hline & & & & & \multicolumn{2}{|c|}{ Health index } \\
\hline Age at death, Bio Mother & $\begin{array}{c}1.0049 \\
(0.0220)\end{array}$ & & $\begin{array}{c}-0.0009 \\
(0.0009)\end{array}$ & & $\begin{array}{c}-0.0000 \\
(0.0001)\end{array}$ & \\
\hline Age at death, Ad Mother & $\begin{array}{c}0.9880 \\
(0.0138)\end{array}$ & & $\begin{array}{l}-0.0011^{*} \\
(0.0006)\end{array}$ & & $\begin{array}{c}-0.0000 \\
(0.0001)\end{array}$ & \\
\hline Age at death, Ad Father & $\begin{array}{c}1.0278^{*} \\
(0.0165)\end{array}$ & & $\begin{array}{c}0.0005 \\
(0.0006)\end{array}$ & & $\begin{array}{c}0.0001 \\
(0.0001)\end{array}$ & \\
\hline Age at death, AdMother*BioMother & $\begin{array}{c}1.0001 \\
(0.0002)\end{array}$ & & $\begin{array}{c}0.0000 \\
(0.0000)\end{array}$ & & $\begin{array}{c}0.0000 \\
(0.0000)\end{array}$ & \\
\hline Age at death, BioMother*AdFather & $\begin{array}{c}0.9996 * \\
(0.0002)\end{array}$ & & $\begin{array}{c}-0.0000 \\
(0.0000)\end{array}$ & & $\begin{array}{c}-0.0000 \\
(0.0000)\end{array}$ & \\
\hline Years of education, Bio Mother & & $\begin{array}{c}1.0192 \\
(0.0565)\end{array}$ & & $\begin{array}{l}-0.0003 \\
(0.0015)\end{array}$ & & $\begin{array}{c}0.0002 \\
(0.0002)\end{array}$ \\
\hline Years of education, Ad Mother & & $\begin{array}{c}0.9969 \\
(0.0557)\end{array}$ & & $\begin{array}{c}0.0013 \\
(0.0015)\end{array}$ & & $\begin{array}{c}0.0000 \\
(0.0002)\end{array}$ \\
\hline Years of education, Ad Father & & $\begin{array}{c}0.9996 \\
(0.0467)\end{array}$ & & $\begin{array}{c}-0.0019 \\
(0.0013)\end{array}$ & & $\begin{array}{c}0.0001 \\
(0.0002)\end{array}$ \\
\hline Education, AdMother*BioMother & & $\begin{array}{c}0.9969 \\
(0.0063)\end{array}$ & & $\begin{array}{c}-0.0002 \\
(0.0002)\end{array}$ & & $\begin{array}{c}-0.0000 \\
(0.0000)\end{array}$ \\
\hline Education, BioMother*AdFather & & $\begin{array}{c}0.9998 \\
(0.0055)\end{array}$ & & $\begin{array}{c}0.0001 \\
(0.0001)\end{array}$ & & $\begin{array}{c}-0.0000 \\
(0.0000)\end{array}$ \\
\hline$P$-value joint significance: & & & & & & \\
\hline Interactions & 0.1687 & 0.8384 & 0.1161 & 0.3012 & 0.4736 & 0.3515 \\
\hline Observations & 21,206 & 21,206 & 21,059 & 21,059 & 21,059 & 21,059 \\
\hline
\end{tabular}

Note: Results from Cox proportional hazard models in columns (1)-(2) and OLS regressions in columns (3)-(6), using the large sample of adoptees. Standard errors in parentheses; ${ }^{* *}$ significant at $1 \%, * *$ at $5 \%$, ${ }^{*}$ at $10 \%$. Each column represents a separate regression and all regressions include indicators for gender and birth cohort of children, and five-year intervals for parental cohorts. Columns (1), (3) and (5) displays results for associations between parental life expectancy and child mortality (1) and health (3 and 5), including interactions between biological mother and adopting parents' characteristics. Columns (2), (4), and (6) displays associations between parental education and child mortality (2) and health (4 and 6), including interactions between biological mother and adopting parents' characteristics 
Table A12. Mortality among adoptees moving to a different municipality at adoption

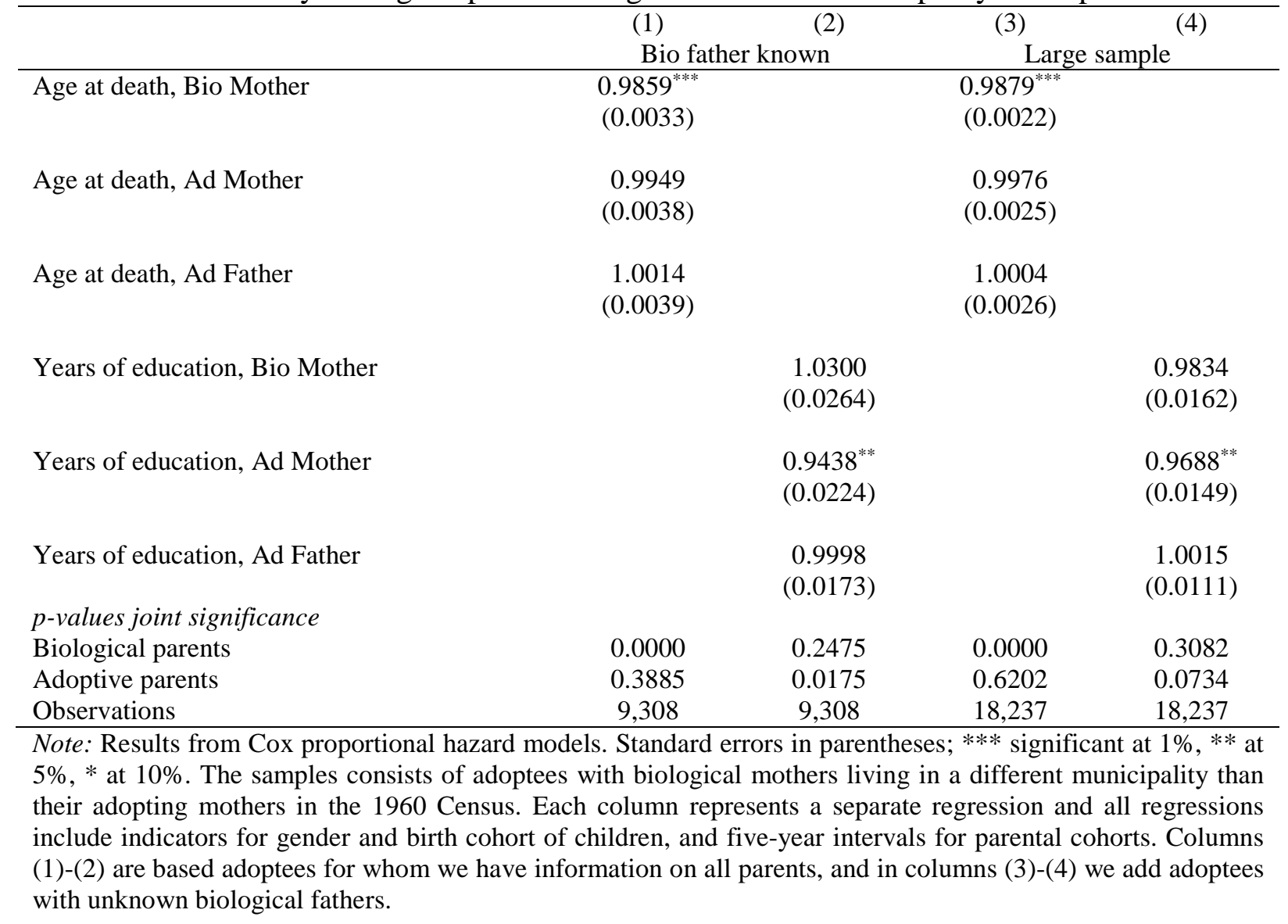


Table A13. Mortality among firstborn adoptees

\begin{tabular}{|c|c|c|c|c|}
\hline & (1) & (2) & (3) & (4) \\
\hline & \multicolumn{2}{|c|}{ Bio father known } & \multicolumn{2}{|c|}{ Large sample } \\
\hline Age at death, Bio Mother & $\begin{array}{l}0.9890^{* *} \\
(0.0049)\end{array}$ & & $\begin{array}{c}0.9862^{* * *} \\
(0.0027)\end{array}$ & \\
\hline Age at death, Ad Mother & $\begin{array}{c}0.9938 \\
(0.0054)\end{array}$ & & $\begin{array}{c}0.9976 \\
(0.0031)\end{array}$ & \\
\hline Age at death, Ad Father & $\begin{array}{c}0.9965 \\
(0.0054)\end{array}$ & & $\begin{array}{c}0.9959 \\
(0.0031)\end{array}$ & \\
\hline Years of education, Bio Mother & & $\begin{array}{l}1.0560^{*} \\
(0.0316)\end{array}$ & & $\begin{array}{c}0.9865 \\
(0.0187)\end{array}$ \\
\hline Years of education, Ad Mother & & $\begin{array}{l}0.9117^{* * *} \\
(0.0283)\end{array}$ & & $\begin{array}{c}0.9435^{* * *} \\
(0.0179)\end{array}$ \\
\hline Years of education, Ad Father & & $\begin{array}{c}1.0133 \\
(0.0225)\end{array}$ & & $\begin{array}{c}1.0045 \\
(0.0135)\end{array}$ \\
\hline p-value joint significance & & & & \\
\hline Biological parents & 0.0252 & 0.0687 & 0.0000 & 0.4730 \\
\hline Adoptive parents & 0.4487 & 0.0080 & 0.3277 & 0.0050 \\
\hline Observations & 4,996 & 4,996 & 11,314 & 11,314 \\
\hline
\end{tabular}

